\title{
Új módszer alkáli bazaltos magmák olivin- és klinopiroxén-frakcionációjának modellezésére
}

\author{
SÁGi Tamás ${ }^{1,2 *}$ Jankovics M. Éva² ${ }^{2}$ Kiss Balázs ${ }^{3}$, NTAFlos Theodoros ${ }^{4}$, Harangi Szabolcs ${ }^{1,2}$ \\ 'Eötvös Loránd Tudományegyetem, Földrajz- és Földtudományi Intézet, Kőzettan-Geokémiai Tanszék, Budapest \\ ${ }^{2}$ MTA-ELTE Vulkanológiai Kutatócsoport, Budapest \\ ${ }^{3}$ Eötvös Loránd Tudományegyetem, Földrajz- és Földtudományi Intézet, Budapest \\ ${ }^{4}$ Universität Wien, Fakultät für Geowissenschaften, Geographie und Astronomie, Department für Lithosphärenforschung \\ *levelező szerző: sagi.tamas@ ttk.elte.hu
}

\section{A new method for the olivine- and clinopyroxene fractionation modelling of alkaline basaltic magmas}

Abstract

The generation and evolution of basaltic magmas which were the result of eruptions in monogenetic volcanic fields have recently been of interest worldwide in connection with volcanological studies. These magmas are of diverse temporal and spatial distribution, and there is considerable variety in their respective modal and chemical compositions, With respect to these facts, the Neogene-Quaternary monogenetic alkaline basaltic volcanic fields of the CarpathianPannonian region (CPR) can be considered as natural laboratories for basaltic magmas. A number of research studies have been published in the last three decades, but these were based on trace element modelling and were performed to characterise only the mantle source lithology or to calculate parental melt compositions. Furthermore, in this process primitive magma calculations were used, based on olivine fractionation or simply with olivine $+/-$ clinopyroxene addition. The widely used parental melt calculations are less accurate if clinopyroxene fractionation occurred (or even if the source rock contained pyroxenite as well). This is because these are based on the major, or trace element compositions of olivine phyric ocean island basalts and peridotites. The principle of such calculations is to generate parental melt compositions through olivine addition.

Based on some alkaline basaltic rocks from the CPR, for this study a new fractionation calculation method was carried out for olivine and/or clinopyroxene phyric intracontinental alkaline basalts. It was designed to calculate the amount of olivine \pm clinopyroxene that fractionated from the parental basaltic melt using only the major elements and the Ni concentration of the basaltic rock, as well as the forsterite and Ni content of its olivine phenocrysts. Based on the degree of fractionation, the model is suitable for estimating the major element composition of the parental melt and its value.

Keywords: alkaline basalt, olivine- and clinopyroxene fractionation, parental (primitive) melt

\section{Összefoglalás}

A monogenetikus vulkáni mezőket felépítő bazaltos magmák képződésének, fejlődéstörténetének vizsgálata a modern vulkanológiai kutatások egyik legfontosabb kérdésköre. A Kárpát-Pannon térségben számos neogén-kvarter monogenetikus alkáli bazalt vulkáni terület található, amelyek képződményei változatos földrajzi elterjedésük, koruk és összetételük révén az intrakontinentális alkáli bazaltok természetes laboratóriumai. Az elmúlt három évtizedben számos tanulmány jelent meg e bazaltos magmák genezise kapcsán, azonban a kutatások vagy csak a földköpenybeli forráskőzet alapvető kőzettani tulajdonságaira irányultak, vagy olivin frakcionáció alapú primitívmagma-kalkulátorok segítségével — esetleg egyszerú olivin \pm klinopiroxén hozzáadással — a szülőmagma összetételére is becslést adtak. A közismert primitívmagma-összetételt számoló programok azonban pontatlan eredményt adnak klinopiroxén-frakcionált magmák esetében (és akár piroxenit-tartalmú forráskőzet esetében is), mivel ezeket olivin-fíros óceáni szigeti bazaltok és peridotitok fő- vagy nyomelemtartalma alapján dolgozták ki, és alapelvük a teljeskőzet-összetételhez történő olivin hozzáadás.

A Kárpát-Pannon térség alkáli bazaltos képződményeit felhasználva egy olyan új frakcionációs modellezést dolgoztunk ki, amely olivin- és/vagy klinopiroxén-fíros intrakontinentális alkáli bazaltok esetében alkalmas a két ásvány szülőmagmából frakcionálódott mennyiségének meghatározására csupán a kőzet főelem-összetétele és Ni-tartalma, valamint a benne található olivin fenokristályok forsterit- és Ni-koncentrációja alapján. A frakcionáció mértéke alapján becslést tudunk adni a kőzet szülőmagmájának főelem-összetételére és a -értékére is. 


\section{Bevezetés}

A modern vulkanológiai kutatások egyik fontos kérdésköre a monogenetikus vulkáni mezők alkáli bazaltos képződményeinek kialakulása, a magmaképződéstôl egészen a felszíni folyamatokig (pl. NÉMETH \& KERESZTURI 2015, VALENTINE \& CONNOR 2015, CAŇ́n-TAPIA 2016). Bár a vulkáni területeket felépítő önálló, kis térfogatú tûzhányók rövid ideig múködnek, a vulkáni mezők teljes élettartama több millió év is lehet (pl. NÉMETH 2010). A vulkáni képződmények egy-egy ilyen vulkáni területen belül is nagy változékonyságot mutathatnak mind fizikai vulkanológiai és kôzetszöveti jellemzőikben, mind pedig kémiai összetételükben (pl. VALENTINE \& CONNOR 2015). Az alkáli bazaltok kôzettani és geokémiai vizsgálata lehetőséget nyújt arra, hogy 1.) megbecsüljük a magma feláramlásának sebességét, 2.) kinyomozzuk a felszín felé tartó útja során történt frakcionációs folyamatokat és 3.) a bazalt összetételéből számolt szülőmagma / primitív magma összetétele alapján információt kapjunk a magma keletkezésének körülményeiről és a földköpenybeli forráskőzetéről (pl. részleges olvadás mértéke és mélysége, forráskőzet kőzettani-geokémiai tulajdonságai) (pl. HARANGI et al. 1995, 2013, 2015; SMith et al. 2008; Ali \& NTAFLOS 2011; MCGEE et al. 2011, 2013; MATTSSON 2012; JANKOVICS et al. 2012, 2013, 2015, 2016).

A primitívmagma-összetétel számolások legegyszerúbb módja, hogy a teljeskőzet-összetételhez addig adagolnak nagy Mg-számú olivint \pm klinopiroxént, amíg a szülőmagmának olyan nagy lesz a Mg-száma, hogy már egyensúlyt tarthat a földköpeny peridotit kőzetével (pl. ZAJACZ et al. 2007). Ennél kissé komplikáltabb módszer, ha az óceáni szigeti bazaltok és lehetséges forráskőzetük nyomelemtartalma alapján kidolgozott (KIMURA \& KAWABATA 2015) vagy a felső köpeny átlagos fóelem-összetételét alapul véve készített frakcionációs modellező programok (PUTIRKA et al. 2007; HERZBERG \& AsIMOw 2008, 2015; LEE et al. 2009) segítségével adnak becslést a szülőmagma összetételére. Ezekkel kapcsolatban problémát jelenthet, hogy ezeket kifejezetten olyan alkáli, óceáni szigeti bazaltos képződményekre (pl. Hawaii, Szent Ilona, Kanári-szigetek, Társaságszigetek) fejlesztették ki, amelyek kizárólag olivin frakcionációval eredeztethetôk a primitív olvadékból, így kontinentális alkáli bazaltokra korlátozottan használhatók (ahogy erre e programok szerzői is figyelmeztetnek). Klinopiroxénfrakcionált bazaltok esetében pedig — mivel a primitívmagma-összetételt olivin hozzáadással keresik — minden esetben pontatlan eredményt adnak.

A Kárpát--Pannon térségben több neogén-kvarter alkáli bazaltos monogenetikus vulkáni terület található (1. ábra). E mezốk tûzhányóit létrehozó magmák a felsố köpenyből származnak, kismértékú részleges olvadás során képzôdtek, és változatos frakcionációs folyamatokon mentek keresztül a felszín felé törve (pl. HARANGI et al. 2015). Habár vannak közöttük rendkívül primitív magmák is (pl. HARANGI 2001, SÁGI 2008, JANKOVICS et al. 2012), egyikük összetétele sem képviseli a földköpennyel egyensúlyt tartó primer olvadékot. A Kárpát-Pannon térség alkáli bazaltjainak primitívmagma-összetétel meghatározására eddig a fentebb vázolt modellek segítségével végeztek számolásokat (pl. ZAJACZ et al. 2007, SÁGI 2008, HARANGI et al. 2013).

Jelen tanulmányban bemutatott kísérletünk célja egy új frakcionáció-modellezés kidolgozása olivin- és/vagy klinopiroxén-fíros intrakontinentális alkáli bazaltokra, amelynek segítségével egyben a kőzetek szülő (primitív) magmájának főelem-összetételére is becslést adhatunk.

\section{Analitikai módszerek}

A Putikov (BRE) és a Lukácskő-Sziklás (SAN) lelőhelyeken gyưjtött lávakőzet-minták teljeskőzet-geokémiai elemzése az Acme Labs-nál (Vancouver, Kanada) készült. A kőzeteket porítás után a felületi víz eltávolítása céljából $105{ }^{\circ} \mathrm{C}$-on szárították és a LOI (izzítási veszteség: Loss On Ignition) meghatározásához $1000{ }^{\circ} \mathrm{C}$-on izzították. Ezt követően a pormintákat platina-arany edényben olvasztották meg $\mathrm{Li}_{2} \mathrm{~B}_{4} \mathrm{O}_{7}$-tal elegyítve. A fő- és mellékelemek koncentrációját ICP-ES (kimutatási határ főelemekre és az izzítási veszteségre: $0,01 \mathrm{~m} / \mathrm{m} \%$, kivéve a vas, amelyre $0,04 \mathrm{~m} / \mathrm{m} \%$, $\mathrm{Ba}, \mathrm{Nb}, \mathrm{Zr}$ : 5 ppm, Sc, Sr, Y: rendre 1, 2 és 3 ppm, Ni: 20 ppm), a nyomelemek mennyiségét pedig ICP-MS (kimutatási határ: 0,01-0,5 ppm) technikával mérték. Az esetleges porítási kontaminációt „blank” minták vizsgálatával ellenőrizték.

A Berek (BARC) és a Kissomlyó (KS) lelőhelyekről származó minták teljeskőzet-elemzését szintén a fenti laboratóriumban végezték, de a kőzetösszetételi adatokat szakirodalomból merítettük (HARANGI et al. 2013, JANKOVICS et al. 2015).

A petrográfiai vizsgálatok során Nikon YS2-T polarizációs mikroszkópot és NIS-Elements $\mathrm{Br}$ fotó-szoftvert használtunk, további szöveti vizsgálatokat és az ásványkémiai mérések előkészítését egy AMRAY 1830 I/T6 pásztázó elektronmikroszkóppal végeztük az ELTE TTK FFI Kőzettan-Geokémiai Tanszékén. Az in situ ásványkémai elemzések Bécsben készültek (Universität Wien, Department für Lithosphärenforschung, Labor für Elektronenstrahlmikrosondenanalytik) CAMECA SX100 elektronmikroszondával, amelynek egy energia- és négy hullámhosszdiszperzív detektora van. A mérések során a gyorsítófeszültség $15 \mathrm{kV}$, a mintaáram pedig $20 \mathrm{nA}$ volt. Minden egyes elemre a mérési idő legalább 20 s volt a „csúcs pozícióban" A mintát érő elektronsugár átmérője $1 \mu \mathrm{m}$ volt. Az elemzésekhez természetes és mesterséges sztenderdeket használtunk: albit $(\mathrm{Na})$, olivin $(\mathrm{Mg})$, korund $(\mathrm{Al})$, kvarc (Si), apatit (P), wollastonit (Ca), rutil (Ti), Mg-krómit (Cr), szpesszartin (Mn), almandin, ilmenit (Fe), Ni-oxid (Ni). Minden mérési sorozat elején és végén is végeztünk sztenderd méréseket az elemzések pontosságának ellenőrzésére. A nyers adatok PAP korrekcióját (PouchOU \& PICHOIR 1991) a mikroszonda analitikai szoftvere végezte. A kimutatási határ főelemekre 0,01-0,1 m/m\%, mellék- és 


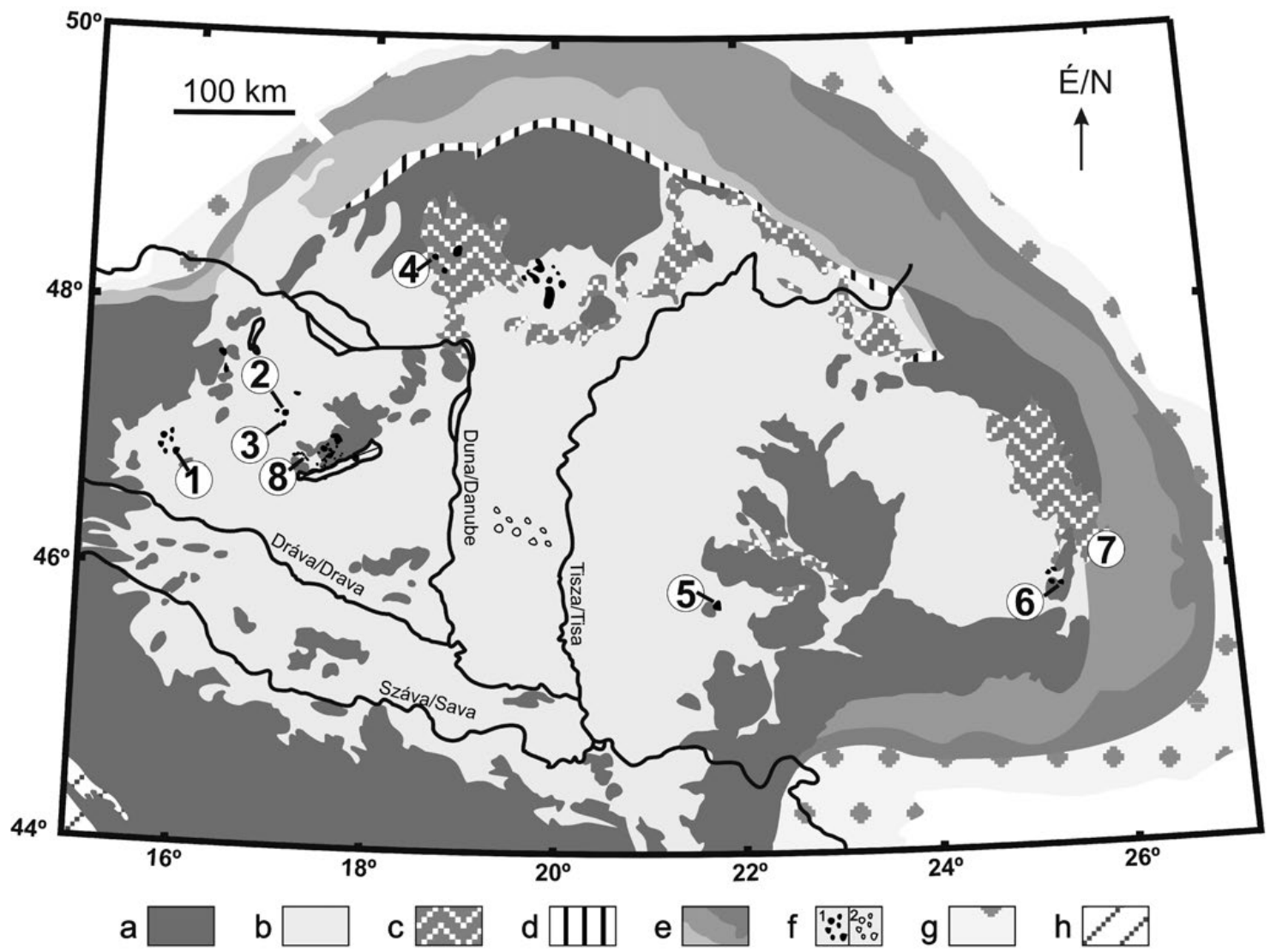

1. ábra. A vizsgált kőzetek lelőhelye. 1 - Steinberg (ST), 2 - Ság-hegy (SAG), 3 - Kissomlyó (KS), 4 - Putikov víšok (BRE), 5 - Sanovita (SAN), 6 - Bârc (BARC), 7 - Csomád (CSOM 1, 2), 8 - Uzsabánya (UZSA)

a - prekainozoos aljzat, b - neogén-kvarter üledékek, c - neogén mészalkáli vulkanitok a felszínen, d - Pieniny-szirtöv, e - Alp-Kárpáti-flisöv, f - neogén-kvarter monogenetikus alkáli bazalt vulkáni mezők: 1 - a felszínen, 2 - eltemetve, g - Alp-Kárpáti-molaszöv, h - Adriai-tenger (Térkép: ALI et al. 2013 és KováČ et al. 2017 alapján)

Figure 1. Locations of investigated samples. 1 - Steinberg (ST), 2 - Ság-hegy (SAG), 3 - Kissomlyó (KS), 4 - Putikov vŕšok (BRE), 5 - Sanovita (SAN), 6 - Bârc (BARC), 7 - Csomád (CSOM 1, 2), 8 - Uzsabánya (UZSA)

$a$ - Pre-Cenozoic basement, $b$ - Neogene-Quaternary sediments, $c$ - Neogene calc-alkaline volcanic rocks on the surface, $d$ - Pieniny Klippen Belt, e - Alp-Carpathian Flysch Belt, $f$-Neogene-Quaternary alkaline basaltic volcanic fields: 1 - on the surface, 2 - buried, $g$ - Alp-Carpathian Molasse Belt, $h$-Adriatic Sea. Large black arrow is facing to north (Map based on ALI et al. 2011 and Kovíč et al. 2017)

nyomelemekre 100-150 ppm, a mérési hiba általában 1\% körül alakult, de a nátrium kivételével minden elem esetében kisebb volt 5\%-nál.

\section{Földtani háttér}

A Kárpát-Pannon térség neogén-kvarter vulkanitjainak kőzettanilag és geokémiailag egyik jól elkülöníthető típusa a miocén-kvarter monogenetikus vulkáni mezők alkáli bazaltos (s.l.) képződményei (pl. HARANGi 2001) (1. ábra). Ezen bazaltos magmák keletkezése ma is vitatott (EMBEYIsZTIN \& DoBOsI 1995; EMBEY-ISZTIN et al. 2001; HARANGI 2001; SEGHEDI et al. 2004; HARANGI \& LENKEY 2007; ALI \& NTAFlos 2011; KovÁcs et al. 2012, Ali et al. 2013; HARANGI et al. 2013, 2015), a legelfogadottabb elméletek szerint az asztenoszféra passzív vagy aktív horizontális és vertikális áramlása okozta dekompresszióhoz köthető kismértékű megolvadása során keletkeztek (HARANGI \& LENKEY 2007, KovÁcs et al. 2012, HARANGI et al. 2015). A legidősebb bazaltok a Burgenland területén (a Pannon-medence nyu- gati peremén) található Pauliberg (Pálhegy) és Oberpullendorf (Felsôpulya) mellett jöttek létre mintegy 11 millió éve (BALOGH et al. 1986, 1994), valamint hasonló korú képződményeket tártak fel szénhidrogén-kutató fúrásokkal az Alföldön, Kecel környékén (BALÁzs \& NusSzER 1987). A bazaltos vulkanizmus legintenzívebb szakasza mintegy 5 és 3 millió évvel ezelőtt volt, ekkor volt aktív a legjelentősebb vulkáni területek, a Bakony-Balaton-felvidék, a SelmecNógrád-Gömör és a Stájer-medence legtöbb túzhányója. A Persányi-hegység vulkánjai ennél fiatalabbak, 0,6-1,2 millió évesek (SEGHEDI et al. 2016), a legfiatalabb pedig a Selmecbányától nyugatra található Putikov vŕšok salakkúpja, amely mindössze $102 \pm 11$ ezer éve képződött (Š́ IMON \& MAGLAY 2005). Ezek az alkáli bazaltos kőzetek nagy összetételi változékonyságot mutatnak a primitív olivinfíros bazanittól a differenciáltabb, olivin- és klinopiroxénfíros fonotefritig (pl. DoBOsi et al. 1998; EMBEY-ISZTIN et al. 1993a, b; HARANGI 2001; HARANGI \& LeNKEY 2007; HARANGI et al. 2015). Kutatástörténetük több mint száz évre nyúlik vissza, az egyszerúbb, leíró-dokumentáló jellegú munkáktól (INKEY 1878; JUGOVICS 1937, 1948, 1972; 
MAURITZ \& HARWOOD 1937a, b; MAURITZ et al. 1948) az egyes kőzetek képződésére, az olvadékok eredetére, fejlődésére és a térség geodinamikai helyzetének jobb megértésére irányuló tanulmányokig (DoBosi et al. 1991, 1995, 1998; ALI \& NTAFlos 2011; Dobosi \& FodOR 1992; EMBEY-IsZTIN et al. 1993a; Downes et al. 1995; EMBEY-ISZTIN \& DoBOSI 1995; ZAJACZ et al. 2007; DOBOSI \& JENNER 1999; KONEČN et al. 1999; HARANGi 2001; HARANGI \& LENKEY 2007; JANKOVICS et al. 2009, 2012, 2013, 2015, 2016; TSCHEGG et al. 2010; SEGHEDI et al. 2011, 2016; KovÁcs et al. 2012; HARANGI et al. 2013, 2015). Az általunk végzett frakcionációs modellezéshez ezen alkáli bazaltok közül választottunk ki olyanokat, amelyek csak olivin vagy olivin + klinopiroxén fenokristályokat tartalmaznak, valamint korban, földrajzi elhelyezkedésben is megfelelően lefedik a KárpátPannon térség alkáli bazaltjait, ugyanakkor nem volt célunk minden egyes vulkáni terület bevonása a vizsgálatba.

Az olivin-piroxén frakcionáció modellezés kiterjesztési lehetőségének vizsgálata céljából e kutatásba bevontuk a csomádi dácitban található mafikus kristálycsomókat is. A Csomád a Kárpát-Pannon térség legfiatalabb tûzhányója (pl. Szakács \& Seghedi 1995; SzaKácS et al. 2002; VINKLER et al. 2007; HARANGI et al. 2010; KARÁTSON et al. 2013, 2016), amely az északról dél felé fiatalodó és egyre kisebb térfogatú vulkánokból felépülő Kelemen-GörgényHargita vulkáni ív délkeleti elvégződésénél található (MASON et al. 1998; Peltz et al. 1987; SzAKÁCS et al. 1993; PÉCSKAY et al. 1995, 1998). GîRBACEA \& FRISCH (1998) szerint a Persányi-hegység alkáli bazaltos vulkanizmusát és a dél-hargitai/csomádi dácitos vulkanizmust közös geodinamikai okokra lehet visszavezetni. A Csomád kutatásának jelentőségét mutatja, hogy számos tanulmány szerint lehetséges a vulkáni múködés felújulása (SzAKÁcs et al. 2002, HARANGi 2007, SZAKÁCS \& SEGHEdi 2013).

\section{A megmintázott képzódmények}

\section{A modellezésnél felhasznált minták lelóhelyei Ny-ról Kfelé haladva (1. ábra)}

Steinberg bei Feldbach, Stájer-medence vulkáni terület (ST)

Feldbach községtől 2 km-rel délkeletre található a Steierische Basalt- und Hartgesteinwerke kôbányája, amely több, mint 50 m vastagságban tárja fel a kezdeti, freatomagmás vulkáni fázis piroklasztitjai feletti salak- és fröccskúpképződményeket és a rájuk települő tefrites és bazanitos összetételú lávafolyásokat. K-Ar kora 2,3-3 millió év (BALOGH et al. 1990). A minta (ST) tömör bazanit lávakőzetből származik (SÁGi 2008).

\section{Ság-hegy, Kisalföld-Kemenesaljai vulkáni terület (SAG)}

Az 5,5 millió éves (BALOGH et al. 1986) Ság-hegy első — freatikus/freatomagmás — kitörései során egy tufagyưrú képződött, ezt követően a szárazabbá váló környezetben stromboli-típusú kitörések során kisebb salakkúpok jöttek létre, illetve fröccskúpok és klasztogenetikus lávafolyások alakultak ki a hawaii-típusú kitörések eredményeként, végül pedig egy lávató töltötte ki a tufagyúrút (HARANGI \& HARANGI 1995). A minta (SAG) az utolsó kitörési fázis során képződött, lemezes elválású trachibazalt lávakőzetből származik (SÁGI 2008).

\section{Kissomlyó, Kisalföld-Kemenesaljai vulkáni terület (KS)}

A Kissomlyó egy összetett monogenetikus vulkáni központ, amely a Ság-hegyhez hasonlóan több különböző kitörési egységből épül fel. A tufagyưrú a kezdeti freatomagmás robbanásos kitöréseket képviseli, amelyre egy tavi üledékes egység települ. A következő egységet párnalávák, párnaláva breccsák és peperitek alkotják, amelyek a tavi üledékes rétegsorba nyomult víz alatti lávafolyás eredményeként képződtek. Ennek felső részén oszlopos elválású lávakőzet (kora 4,63 millió év, WiJBRANS et al. 2007) figyelhető meg, amely a már szárazföldi körülmények között képződött kráteren belüli lávafolyásokat képviseli. A vulkáni felépítmény legtetején egy fröccskúp maradványa található, amely egykori lávaszökőkút-szerú magmás robbanásos kitörésekre utal. A tavi üledékes egység jelenléte azt feltételezi, hogy a tufagyưrű felépülését egy nyugalmi periódus követte, kialakult egy krátertó, amelyben üledékképződés zajlott, majd késôbb felújult a vulkáni múködés (MARTIN \& NÉMETH 2005). A vizsgált minta (KS) az oszlopos bazanit lávakőzetból származik (JANKOVICS et al. 2015).

\section{Uzsabánya, Bakony-Balaton-felvidéki vulkáni terület (UZSA)}

A Keszthelyi-hegységtől északra elhelyezkedő bazaltvulkánok (Uzsa, Szebike, Tátika, Bazsi, Kovácsi-hegy) a vulkáni terület fiatalabb képződményei közé tartoznak, koruk 2,7-3,4 millió év (BALOGH et al. 1986). Közülük a legjelentősebb az Uzsa-hegy. Az Uzsa és Várvölgy községek között, az utóbbi területén található kőfejtőben feltáruló vulkáni képződmények nagy részét lávafolyások és egy egykori lávató maradványa képviselik, ugyanakkor számottevő a freatomagmás kitörésekhez köthetô piroklasztitok menynyisége is (MARTIN \& NÉMETH 2004). A minta (UZSA) az egykori lávató masszív trachibazalt kőzetéból származik (SÁGI 2008).

\section{Putikov vŕšok, Selmeci vulkáni terület (BRE)}

A Brehy (Magasmart) községtől délre található salakkúp és az abból kiinduló lávafolyás az egész Kárpát-Pannon térség legfiatalabb bazaltvulkáni képződménye, kora $102 \pm$ 11 ezer év (ŠımON \& MAGLAY 2005). Az oszloposan elváló bazanit lávakőzetből a Garamhoz közeli kőfejtőben vettünk mintát (BRE).

\section{Lucaret-Sanovița (Lukácskô-Sziklás), Bánát vulkáni terület (SAN)}

A Temesvártól 35 km-rel keletre található két kőfejtőben a rétegsor freatomagmás képződményekkel kezdődik, ame- 
lyeket lávakőzetek fednek, legfelül pedig stromboli-típusú kitörések során keletkezett salakkúpok találhatók (TsCHEGG et al. 2010). E két kőfejtő kőzete 2,5-2,6 millió éves (DownES et al. 1995) trachibazalt. A mintavételezés a lávakőzetből történt (SAN).

\section{Bârc (Berek), Persányi-hegységi vulkáni terület (BARC)}

A mai Berek-völgyben mintegy 1 millió éve (SEGHEDI et al. 2016) létrejött tufagyưrú kráterét utolsó kitörései során egy lávató töltötte ki, ami a kráter északkeleti falát átszakította és így egy lávafolyás képződött. A maar vulkán kráterének keleti peremén, a Persányi-hegység következő vulkáni fázisában egy salakkúp jött létre, aminek lávafolyása a tufagyưrúből eredő, idôsebb berek-völgyi bazaltokkal közvetlenül érintkezik. A vizsgált, fiatalabb trachibazalt lávakőzet kora 0,799 \pm 0,021 millió év (SEGHEDI et al. 2016), a minta (BARC) a völgy 13-as (E 60) fôuthoz közeli részében lévő kőfejtôből származik (HARANGI et al. 2013). A lávafolyást HARANGI et al. (2013) a közeli Bükkösd (Gruiu) salakkúphoz kötötték.

\section{A modellezés lehetséges kiterjesztéséhez felhasznált minták lelóhelye (1. ábra)}

\section{Csomád}

A Csomád vulkán kivételt képez, mivel a többi vizsgált képződménnyel szemben ez nem alkáli bazaltvulkán, hanem a Kelemen-Görgény-Hargita andezites-dácitos mészalkáli vulkáni összlet legfiatalabb tagja. A tûzhányót magas K-tartalmú dácit építi fel. Az itt vizsgált minták (CSOM1, 2) a KISs (2014) és a KIss et al. (2014) tanulmányokban bemutatott, az északi kráterperemről származó 100-150 ezer éves dácit lávakőzetekben megjelenő mafikus kristálycsomókat képviselik.

\section{Petrográfia}

\section{Alkáli bazaltok}

A modell kidolgozásához használt alkáli bazaltok (s.l.) mindegyike masszív lávakőzet. Részletes petrográfiai adataikat az I. táblázat, általános szöveti fotóikat a 2. ábra tartalmazza. Szövetük és ásványos összetételük alapján három csoportba sorolhatók.

\section{1-es típus}

E kőzetek porfíros intergranuláris szövetúek, fenokristályként csak olivin (SAG, BARC) vagy olivin és elenyésző mennyiségû klinopiroxén (BRE, UZSA) jelenik meg (2. ábra, a). Az olivin fenokristályok normál zónásak, általában félig sajátalakúak-sajátalakúak, a nagyobb olivinszemcsék gyakran rezorbeáltak (ez esetben gyakran nem sajátalakúak), és peremük, hasadási nyomvonalaik mentén iddingzitesedtek. Általában önálló kristályokként jelennek meg, két mintában (SAG, UZSA) előfordulnak néhány olivinszemcséból álló glomerokristályok is. Átlagos méretük 650-700 $\mu \mathrm{m}$, a legnagyobb kristályok 1800-2500 $\mu$ m-esek. A bereki (BARC) mintában csak 300-400 $\mu \mathrm{m}$-esek az olivinek, és a legnagyobb kristályok mérete sem haladja meg a $800 \mu \mathrm{m}$-t. Az alapanyag összetétele mindegyik kőzetben hasonló, mintegy 40-85\%-a plagioklász, 5-40\% között változik a klinopiroxén és 5$15 \%$ között az olivin (a kisebb szemcsék gyakran teljesen iddingzitesedettek) mennyisége, ezeken kívül megjelenik még magnetit, ilmenit (SAG, BRE) és nefelin (BRE, BARC) is.

\section{2-es típus}

Átmeneti tag az 1-es és a 3-as típus között, csak egy minta (SAN) tartozik ide. A kőzet szövete és alapanyagának ásványos összetétele megegyezik az 1-es típusba sorolt kőzetekével. Habár itt is az olivin az uralkodó fenokristály, a klinopiroxének jóval nagyobb arányban ( 20-25\%) fordulnak elő (2. ábra, $b$ ). A fenokristályok közül az olivinek normál zónásak, félig sajátalakúak vagy sajátalakúak, gyakran rezorbeáltak, méretuik átlagosan $500 \mu$ m és legfeljebb 1200 $\mu \mathrm{m}$. A klinopiroxén fenokristályok szektor zónásak, félig sajátalakúak és sajátalakúak, általában néhány szemcséből álló glomerokristályokat alkotnak. Méretük átlagosan 300$400 \mu \mathrm{m}$, legfeljebb $1000 \mu \mathrm{m}$.

\section{3-as típus}

Két minta tartozik ebbe a típusba (KS, ST). Szövetük glomeroporfíros intergranuláris (KS), illetve interszertális (ST). Fenokristályként klinopiroxén és olivin jelenik meg, a piroxén az uralkodó (2. ábra, c). A kissomlyói minta esetében a porfíros elegyrészek szinte kivétel nélkül glomerokristályokként jelennek meg, a steinbergi kőzetben ez főleg a klinopiroxénekre jellemzô, az olivinek gyakrabban fordulnak elő önálló kristályként. A fenokristályok általában félig

I. táblázat. A vizsgált bazalt kőzetminták részletes petrográfiai jellemzői

Table I. Detailed petrographical characteristics of the investigated basaltic samples

\begin{tabular}{|l|l|r|c|c|c|}
\hline \multicolumn{2}{|c|}{ Minta } & \multicolumn{2}{|c|}{$\Sigma \%$ fenokristály; (arány) } & Alapanyag & Szövet \\
\hline ST & bazanit & 17,5 & ol, cpx (3/7) & plag, cpx, ol, mt, gl & glomeroporfiros-isz. \\
\hline SAG & trachibazalt & 10 & ol & plag, ol, cpx, mt, ilm & porfíros-ig. \\
\hline KS & bazanit & 20 & ol, cpx (2/8) & plag, cpx, mt, ol, ap & glomeroporfíros-ig. \\
\hline UZSA & trachibazalt & 10 & ol, cpx (19/1) & plag, cpx, ol, mt & porfiros-ig. \\
\hline BRE & bazanit & 6 & ol, cpx (19/1) & plag, ol, cpx, mt, ne & porfíros-ig. \\
\hline SAN & trachibazalt & 20 & ol, cpx (4/1) & plag, cpx, ol, mt & porfíros-ig. \\
\hline BARC & trachibazalt & 5 & \multicolumn{1}{c|}{ ol } & plag, cpx, ol, mt & porfiros-ig. \\
\hline
\end{tabular}

$\mathrm{ol}=\mathrm{olivin} /$ olivine, $\mathrm{cpx}=\mathrm{klinopiroxén} /$ clinopyroxene, $\mathrm{plag}=$ plagioklász/plagioclase, $\mathrm{mt}=$ magnetit $/$ magnetite, $\mathrm{ilm}$ $=$ ilmenit/ilmenite, ap = apatit/apatite, ne = nefelin/nepheline, $\mathrm{gl}=$ kőzetüveg/glass, ig. = intergranuláris/intergranular texture, isz. $=$ interszertális/intersertal texture 

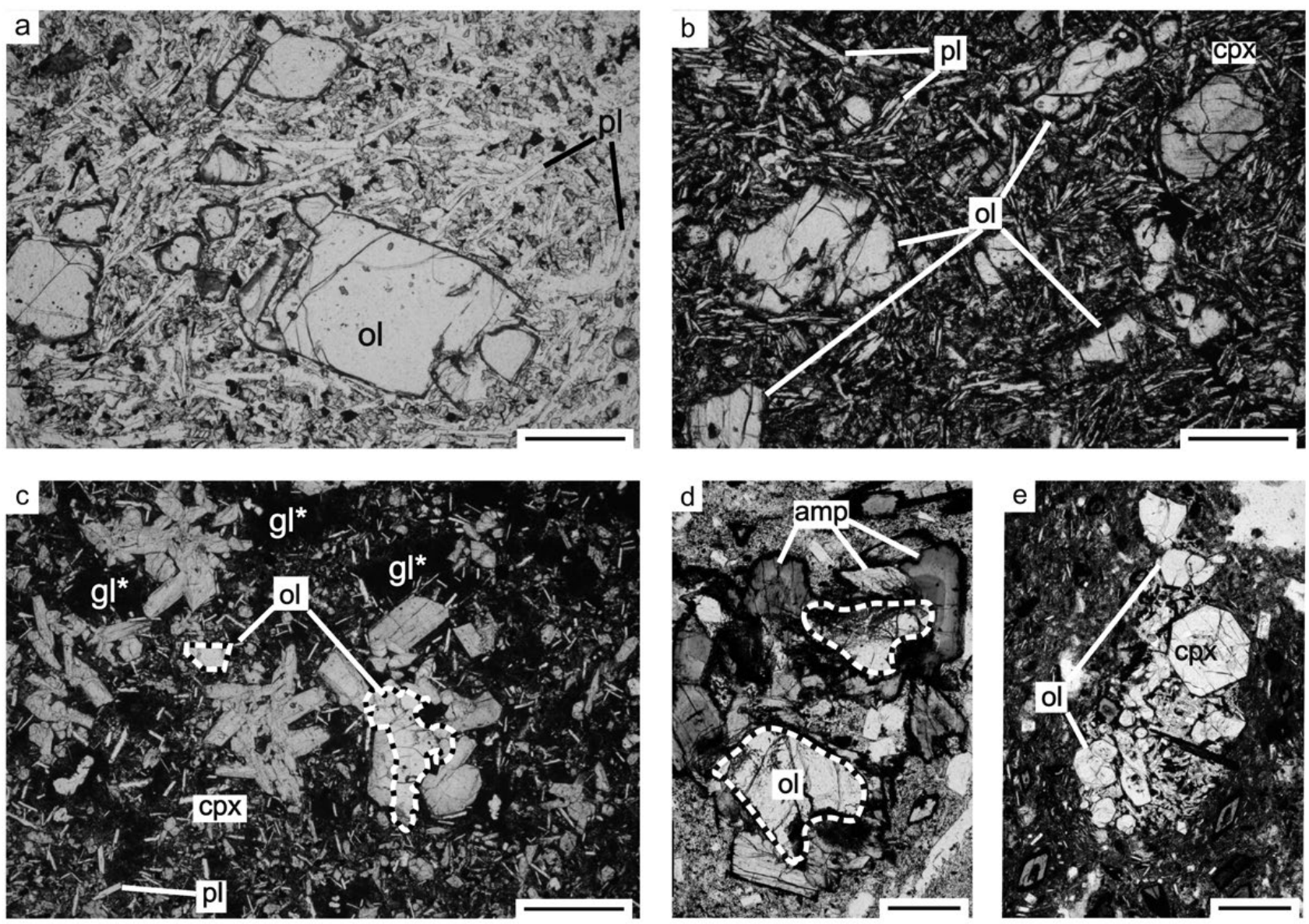

2. ábra. A vizsgált alkáli bazaltok (a-c) és a csomádi mafikus kristálycsomók (d-e) általános szöveti képe (polarizációs mikroszkópos fotók, 1N). A fekete vonal a fényképek jobb alsó sarkában $500 \mu \mathrm{m}$ hosszúságú

amp = amfibol, $\mathrm{cpx}=$ klinopiroxén, $\mathrm{gl}{ }^{*}$ = kőzetüveggazdag terület az alapanyagban, ol = olivin, $\mathrm{pl}$ = plagioklász. Az olivin kristályok körvonalát fekete-fehér szaggatott vonallal emeltük ki a (c) és (d) képeken. a) Az 1-es típusú (olivin-fíros) alkáli bazaltok egyik példánya (SAG). A plagioklász-gazdag alapanyagban nagyméretű, iddingzitesedett peremű olivin fenokristályok jelennek meg. b) A 2-es típusú (olivin-piroxén-fíros) alkáli bazalt egyetlen képviselője (SAN). A fenokristályok mintegy 20\%-át adják a klinopiroxének. Az alapanyagban a plagioklász az uralkodó, de jóval több a klinopiroxén és a magnetit, mint az 1-es típusnál. c) A 3-as típusú (piroxén-fíros) alkáli bazaltok egyik példánya (ST). A fenokristályok nagy része klinopiroxén glomerokristály. Az alapanyagban jelentős mennyiségủ kőzetüveg található. d) A csomádi 1. típusú kristálycsomók (CSOM 1) egyik példánya. Az olivinek körül fekete reakciószegély és amfibol ránövekedés figyelhető meg. e) A csomádi 2. típusú kristálycsomók (CSOM 2) egyik példánya. Fő alkotója a klinopiroxén, illetve alapanyaguk is van. Az olivinszemcsék körül itt nincs reakciószegély

Figure 2. General textures of alkaline basalts ( $a-c)$ and mafic crystal clots from the Csomád (d-e). Micrographs were taken with polarizing microscope (PPL), black bars at the bottom right corners represent $500 \mu \mathrm{m}$

amp $=$ amphibole, $c p x=$ clinopyroxene, $g l^{*}=$ glass rich areas of the groundmass, ol $=$ oivine, $p l=$ plagioclase. Olivine phenocrysts were outlined with dashed black \& white lines on pictures ' $c$ ' and 'd'. a) A sample (SAG) from the $1^{\text {st }}$ type of alkaline basalts (olivine phyric). Olivine phenocrysts with iddingsitized rims in a plagioclase rich groundmass. b) The sole representative (SAN) of the $2^{\text {nd }}$ type (olivine-pyroxene phyric). $\sim 20 \%$ of phenocrysts are clinopyroxenes. Plagioclase laths are dominant in the groundmass however there are more clinopyroxene and magnetite crystals as in the $1^{\text {st }}$ type. c) A sample (ST) from the $3^{\text {rd }}$ type (pyroxene phyric). Most of the phenocrysts are clinopyroxene glomerocrysts. The groundmass contains a significant amount of glass. d) A $1^{\text {st }}$ type mafic crystal clot of the Csomád dacite (CSOM 1). Olivine crystals are surrounded by black reaction rims and they are overgrown by amphiboles. e) A $2^{\text {nd }}$ type mafic crystal clot (CSOM 2). It contains groundmass and the most abundant phenocryst phase is clinopyroxene. Olivine grains are fresh without reaction rims

sajátalakúak vagy sajátalakúak. A kissomlyói mintában (KS) a klinopiroxének szektor zónásak, méretük átlagosan 400-500 $\mu \mathrm{m}$ és legfeljebb $1800 \mu \mathrm{m}$. Az olivinek 200-900 $\mu \mathrm{m}$ mérettarományban mozognak, sajátalakúak - félig sajátalakúak, és bár változatos szöveti és zónássági bélyegeket mutatnak (JANKOVICS et al. 2015), nagy többségük vázkristályos és normál zónás. A legnagyobb klinopiroxén és/vagy olivin glomerokristályok $1600 \mu \mathrm{m}$-esek. A steinbergi mintában (ST) a klinopiroxének szintén szektor zónásak. Méretük átlagosan 450-500 $\mu \mathrm{m}$, legfeljebb 1200 $\mu \mathrm{m}$. A piroxén glomerokristályok átlagos mérete 800-900 $\mu \mathrm{m}$, a legnagyobbaké az 1500-2000 $\mu \mathrm{m}$-t is eléri. Az olivinek normál zónásak, félig sajátalakúak vagy sajátalakúak. Méretük átlagosan 500-600 m, legfeljebb 2000 $\mu$ m. Általában önálló szemcsék, vagy néhány olivinkristályból álló glomerokristályok formájában jelennek meg, de előfordulnak olivin-klinopiroxén glomerokristályok is.

Az olivinek iddingzitesedése csak a steinbergi mintában jellemző. Az alapanyag összetételében is van eltérés a két minta között. Steinberg esetében az alapanyag alkotói: $\sim 50 \%$ klinopiroxén, 20-25\% plagiokolász, 10\% olivin, 5$10 \%$ magnetit és kőzetüveg, továbbá előfordul még rhönit és szanidin is kevesebb, mint $1 \%$-nyi mennyiségben. A kissomlyói minta alapanyagában a plagioklász ( 65\%) és a klinopiroxén ( 20\%) az uralkodó. E kőzet alapanyaga a leggazdagabb magnetitben $(\sim 10 \%)$, emellett még kevés olivint $(\sim 4 \%)$ és apatitot $(\sim 1 \%)$ tartalmaz. 


\section{Csomádi mafikus kristálycsomók}

A csomádi dácitban megjelenő mafikus kristálycsomók modális összetételük alapján két fő csoportra oszthatók.

1. típus (CSOM1, 2. ábra, d): mindössze a kristálycsomók 5\%-a tartozik ide, méretük 0,5-2 mm, olivin- és amfibolkristályokból állnak. Az olivinkristályok nem sajátalakúak, nagymértékben rezorbeáltak, szubmikronos méretú vas-oxid túk hálózzák be ôket, valamint 5-10 $\mu$ m nagyságú Cr-spinell zárványokat is tartalmaznak. Az olivin körül egy finomszemcsés, fóként piroxénekből (és oxidokból) álló reakciózóna jelenik meg, amelyet zónás amfibolok ölelnek körbe. Az apró vas-oxid túk jellemzően az olivin reakciózónához közeli részén jelennek meg, az olivinek magja azonban általában ép.

2. típus (CSOM2, 2. ábra, e): ide tartozik a kristálycsomók nagy része, méretük $2-3 \mathrm{~mm}$, klinopiroxént \pm olivint \pm amfibolt tartalmaznak. Itt az olivin csak kismértékú rezorpciót mutat, nem jelennek meg benne vas-oxid túk, és reakciózóna megjelenése sem jellemző rá. E kristálycsomók gyakran glomeroporfíros szövettel jellemezhető́k, amelyekben alapanyag (plagioklász, Fe-Ti-oxidok, káliföldpát, kristályos $\mathrm{SiO}_{2}$ ) is található.

\section{Geokémia}

\section{Adatok}

Amely mintákból rendelkezésre állt megbízható, publikált olivin és/vagy klinopiroxén adatsor (megbízhatónak azokat az adatokat tekintettük, amelyek esetében a mérések ugyanabban a laborban történtek, mint ahol a saját elemzéseket végeztük: Universität Wien, Department für Lithosphärenforschung, Labor für Elektronenstrahlmikrosondenanalytik), azokat felhasználtuk, a többi kőzet esetében pedig új méréseket végeztünk. A felhasznált szakirodalmi adatok a következők: Bârc (BARC): olivin adatok (HARANGI et al. 2013), Csomád (CSOM 1, 2): olivin adatok (KIss 2014, Kiss et al. 2014), Kissomlyó (KS): olivin és klinopiroxén adatok (JANKOVICS et al. 2015), Ság-hegy (SAG): olivin adatok (SÁGI 2008), Sanovița (SAN): klinopiroxén adatok (TSCHEGG et al. 2010), Steinberg (ST): olivin (ALI et al. 2013, SÁGI 2008) és klinopiroxén adatok (ALI et al. 2013), Uzsabánya (UZSA): kiegészítő olivin adatok (SÁGI 2008).
Új mérésekre volt szükség az alábbi mintákból: Putikov vŕšok (BRE), Sanovița (SAN): teljeskőzet-összetétel és olivin adatok, Uzsabánya (UZSA): olivin adatok.

A teljeskôzet-összetétel adatokat — ahol rendelkezésre álltak - szintén a szakirodalomból vettük. BARC: HARANGi et al. (2013), KS: JANKOVICS et al. (2015), SAG: HARANGi et al. (1995), ST, UZSA: EMBEY-IsZTin et al. (1993a, b).

\section{Teljeskózet-geokémia}

$\mathrm{SiO}_{2}$ - és összalkália-tartalmuk alapján a vizsgált minták közül négy trachibazalt: BARC, SAG, SAN, UZSA és három bazanit: BRE, KS, ST (3. ábra, a). Fóelemösszetételüket a II. táblázat tartalmazza. Két kôzet Mg\#-a nagy (BRE: 67,9 és BARC: 67,2), négyé közepes (SAG: 64,6, UZSA: 64,1, SAN: 63.9, KS: 63,2) és egy mintáé kifejezetten kicsi (ST: 58,2). $\mathrm{Mg} \#=\mathrm{Mg} /\left(\mathrm{Mg}+\mathrm{Fe}^{2+}\right) \times 100$, $0,15 \mathrm{Fe}_{2} \mathrm{O}_{3} / \mathrm{FeO}$ arányt feltételezve, $\mathrm{Mg}$ és $\mathrm{Fe}^{2+}$ kation molfrakció értékek.

\section{Olivin}

Az olivinek döntő többsége esetében 80-85 mol\% Fotartalom jellemzô. A kristályok normál zónásak, magjuk

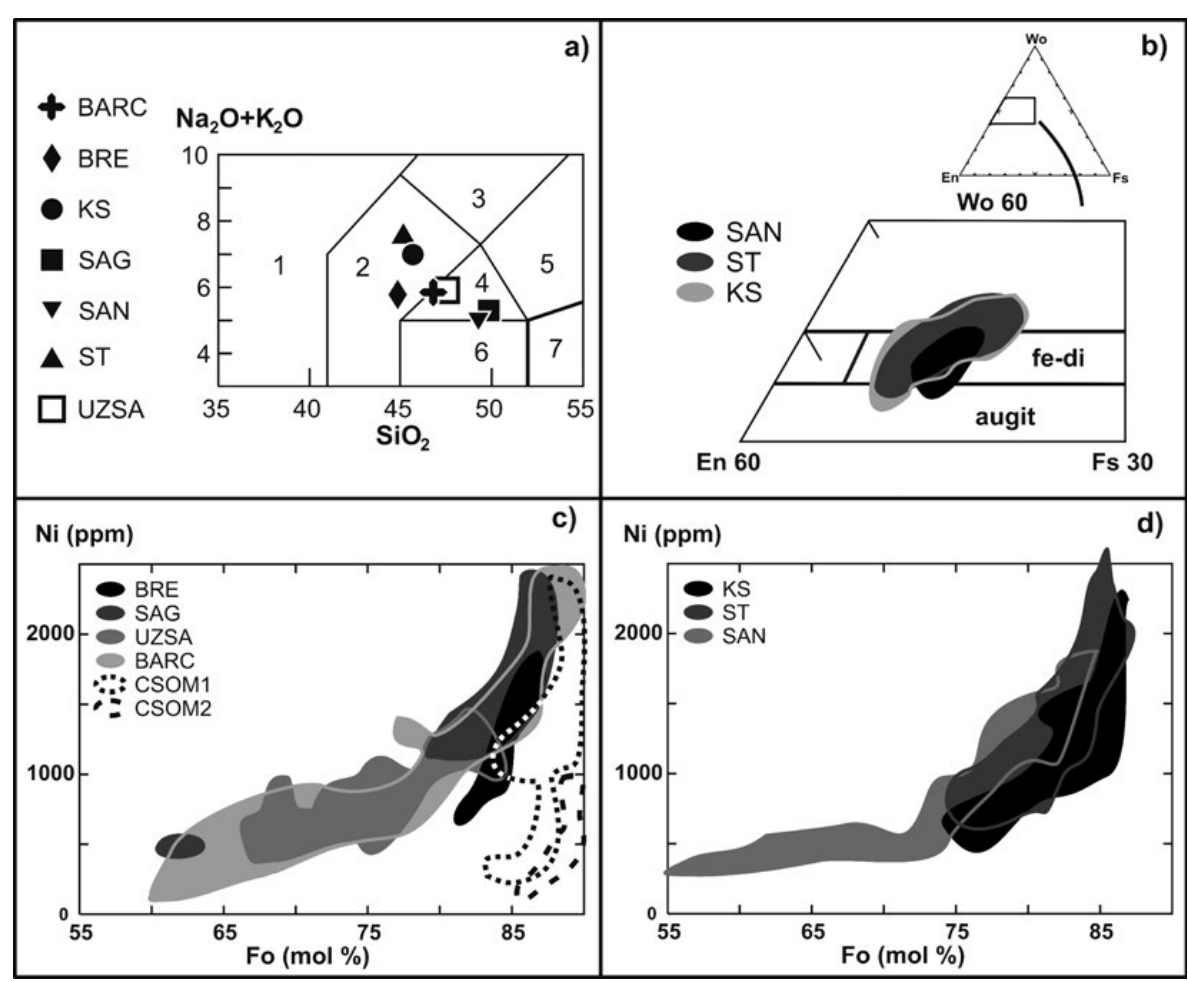

3. ábra. a) A modellezéshez használt alkáli bazaltok összetétele a TAS-diagramon (LE BAS et al. 1992)

1 - foidit, 2 - tefrit-bazanit, 3 - fonotefrit, 4 - trachibazalt, 5 - bazaltos trachiandezit, 6 - bazalt, 7 - bazaltos andezit. b) A felhasznált klinopiroxének összetétele. c) Az 1-es típusú alkáli bazaltok (szürke mezők) és a csomádi mafikus kristálycsomók olivinjeinek összetétele (pöttyözött és szaggatott körvonalú területek). d) A 2-es típusú (SAN) és a 3-as típusú (KS, ST) bazaltminták olivinkristályainak összetétele

Figure 3. a) Composition of investigated alkaline basalts on the TAS diagram (LE BAS et al. 1992).

1 - foidite, 2 - tephrite-basanite, 3 - phonotephrite, 4 - trachybasalt, 5 - basaltic trachyandesite, 6 - basalt, 7 - basaltic andesite. b) Composition of clinopyroxenes used in the modeling. c) Composition of olivines from the $1^{\text {st }}$ type of alkaline basalts (grey areas) and from mafic crystal clots of the Csomád dacite (areas with dotted and dashed outlines). $d$ ) Composition of olivines from the $2^{\text {nd }}(S A N)$ and $3^{\text {rd }}(K S, S T)$ types of alkaline basalts 
II. táblázat. A vizsgált kőzetminták teljeskőzet-összetétele. Az oxidok és az izzítási veszteség (LOI) tömeg \%-os értékben, a Ni és Cr pedig ppm-ben vannak megadva

Table II. Composition of investigated basaltic samples. Oxides and LOI are given in wt. \%, Ni and Cr in ppm

\begin{tabular}{|c|c|c|c|c|c|c|c|c|}
\hline Minta & & SAG & UZSA & BRE & BARC & ST & SAN & KS \\
\hline Lelöhely & & Ság-hegy & Uzsa & Putikov vŕšok & Bârc & Steinberg & Sanovița & Kissomlyó \\
\hline \multirow{2}{*}{$\mathrm{GPS}$} & $E$ & 47,23058 & 46,88809 & 48,40336 & 45,95409 & 46,93337 & 45,81060 & 47,14819 \\
\cline { 2 - 9 } & $K$ & 17,11614 & 17,31597 & 18,63353 & 25,35795 & 15,91738 & 21,71761 & 17,09849 \\
\hline \multirow{2}{*}{$\mathrm{SiO}}$, & & 49,79 & 46,18 & 44,71 & 46,63 & 45,57 & 48,90 & 44,94 \\
\hline $\mathrm{TiO}_{2}$ & & 2,13 & 2 & 2,46 & 1,77 & 2,02 & 2,19 & 2,31 \\
\hline $\mathrm{Al}_{2} \mathrm{O}_{3}$ & & 15,83 & 15,2 & 13,18 & 15,95 & 15,08 & 14,68 & 14,80 \\
\hline $\mathrm{Fe}, \mathrm{O}_{3}^{\text {total }}$ & & 9,98 & 10,16 & 11,6 & 10,12 & 11,70 & 10,71 & 10,72 \\
\hline $\mathrm{MnO}$ & & 0,14 & 0,16 & 0,17 & 0,17 & 0,17 & 0,15 & 0,17 \\
\hline $\mathrm{MgO}$ & & 8,03 & 8,05 & 10,91 & 9,22 & 7,25 & 8,43 & 8,19 \\
\hline $\mathrm{CaO}$ & & 8,24 & 8,96 & 10,08 & 9,44 & 10,58 & 8,52 & 9,46 \\
\hline $\mathrm{Na}, \mathrm{O}$ & & 3,33 & 3,65 & 4,04 & 3,91 & 5,45 & 3,39 & 4,36 \\
\hline $\mathrm{K}, \mathrm{O}$ & & 1,96 & 2,09 & 1,72 & 1,91 & 2,14 & 1,63 & 2,52 \\
\hline $\mathrm{P}, \mathrm{O}_{5}$ & & 0,49 & 0,71 & 0,77 & 0,48 & 0,89 & 0,60 & 0,88 \\
\hline $\mathrm{LOI}$ & & 0,88 & 2,4 & 0 & 0 & 0,50 & 0,80 & 1,10 \\
\hline $\mathrm{Ni}$ & & 205 & 129 & 219 & 179 & 79 & 170 & 114 \\
\hline $\mathrm{Cr}$ & & 350 & 171 & 342 & 315 & 181 & 247 & 236 \\
\hline
\end{tabular}

Fo-tartalma jellemzően 75-90 mol\% közötti, míg peremük magnéziumban szegényebb (55-75 mol\% Fo, amelyek közül a többség a $\mathrm{Fo}_{65-75}$ tartományba esik). Nikkeltartalmuk pozitívan korrelál a forsterittel, a magnéziumban gazdagabb kristálymagok esetében 1800-2600 ppm-et is elér a Ni koncentrációja, míg a szemcsék peremén jellemzôen 700 ppm alatti, de akár 100 ppm-re is csökkenhet (3. ábra, c, d). A csomádi mafikus kristálycsomók esetében a CSOM 1 minta (1. típusú mafikus kristálycsomók) olivinjeinek Fotartalma 85-90 mol\%, Ni-koncentrációja pedig 100-1000 ppm között változik. Ugyanezek az értékek a CSOM 2 minta (2. típusú mafikus kristálycsomók) olivinjei esetében 83-90 mol\% Fo és 250-2450 ppm Ni (3. ábra, c).

\section{Klinopiroxén}

A klinopiroxén fenokristályokat is tartalmazó minták (KS, ST, SAN) piroxénjeinek összetétele egymáshoz hasonló: többségük vas-diopszid és augit, de a steinbergi és a kissomlyói kőzetek esetében előfordulnak 60 mol\%-nál több wollastonit komponenst tartalmazó kristályok is (3. ábra, b). A kristályok szektor zónásak, magjuk 12,9-15,9 m/m\%, peremük pedig 10,4-13,9 m/m\% MgO-t tartalmaz. CaOtartalmuk 20,6-23,1 m/m\% (mag) és 22,3-23,6 m/m\% (perem) között változik.

\section{Olivin- és klinopiroxén frakcionáció modellezése}

Kevéssé frakcionált alkáli bazaltok és fơképp a belőlük származtatott primitívmagma összetétele alapján következtethetünk a földköpenybeli forráskőzet összetételére, megolvadásának mértékére és mélységére, valamint a földköpeny potenciális hőmérsékletére (pl. HERZBERG \& O'HARA 2002; NIU \& O'HARA 2003; PUTIRKA 2005;
Herzberg et al. 2007; Herzberg \& Asimow 2008, 2015; PiLET et al. 2008; LeE et al. 2009; HerZBERG 2011).

A közismert primitivmagma-kalkulátorokat (HERZBERG \& AsIMOw 2008, 2015; LEE et al. 2009) óceáni szigeteki vagy platóbazaltok kôzetei alapján dolgozták ki, és ezek a teljes kőzet főelem-összetételhez való olivin-adagolással keresik a bazaltos olvadékok összetételét. Az olivin-hozzáadással történő számolás problémát jelenthet, amennyiben a forráskőzet nem tisztán peridotit, hanem részben vagy teljesen piroxenit, illetve még inkább pontatlansághoz vezet, ha a primitív magmából nem csak olivin, de klinopiroxén kristályosodása is történt (HERZBERG \& AsIMOW 2008). Ez utóbbi esetben a ténylegeshez képest felül fogjuk becsülni a primitív magma $\mathrm{MgO}$-tartalmát (akár több \%ponttal), Mg\#-át és — mivel szoros függést mutatnak — a köpeny potenciális hőmérsékletét is (akár $100{ }^{\circ} \mathrm{C}$-kal) (HERZBerg \& AsIMOw 2008). Piroxenittartalmú peridotit olvadásának modellezésére a leginkább használható, a bazaltok és a lehetséges forráskőzetek nyomelem-összetételén alapuló modellt KimURA \& KaWABATA (2015) dolgozták ki, azonban ahogy a neve is mutatja (Ocean Basalt Simulator), ezt is OIB kőzetek alapján fejlesztették ki, továbbá piroxén frakcionáció esetében a primitívmagmaösszetétel modellezése kapcsán felmerülő problémák kiküszöbölésére ez sem jelent biztos megoldást.

Frakcionációs kristályosodás során mind a magma, mind a belőle kiváló kristályok összetétele folyamatosan változik. Amennyiben ezt az összetétel-változást nyomon tudjuk követni, lehetőségünk adódik az olvadékból frakcionálódott kristályok mennyiségének és a szülő (primitív) magma összetételének becslésére.

A Kárpát-Pannon térség neogén-kvarter alkáli bazaltos kőzeteiből frakcionáció modellezés céljára olyanokat választottunk ki, amelyek kizárólag olivin vagy olivin + klinopiroxén fenokristályokat tartalmaznak. 


\section{A modellezés alapja}

Az alkáli bazaltos magmák olivinjei a kristályosodás elôrehaladtával egyre csökkenő $\mathrm{Mg}$ (Fo)- és Ni-koncentrációval jellemezhetők. A magnézium mind a kristály, mind a magma szempontjából fóelem, a nikkel viszont mellék-/ nyomelemként van jelen. Ennek megfelelóen a Ni koncentrációját az olivinben és a vele egyensúlyt tartó olvadékban annak megoszlási együtthatója $\left(D_{N i}^{o l-o l v}\right)$ szabja meg. SATO (1977) eredményeit felhasználva KawABATA et al. (2011) leírták, hogy az alkáli bazaltos olivin-összetételek a Fo-Ni diagramon egy közel exponenciális görbére illeszkednek a Ni- és a Fo-tartalom fokozatos csökkenése mellett, amenynyiben az olvadékból csak olivin frakcionálódott, míg ha az olivinnel együtt klinopiroxén is kristályosodott, akkor a nikkel és forsterit koncentrációjának csökkenése lineáris trendet mutat ugyanezen a diagramon. Az exponenciális görbe meredeksége a $D_{N i}^{o l-o l v}$, a lineáris trend meredeksége

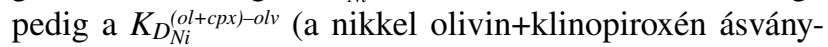
olvadék megoszlási együtthatója) függvénye. KAWABATA et al. (2011) kimutatták, hogy az alkáli bazaltok Fo- és Nigazdag olivinjei gyakran az exponenciális trendre, annak függőlegeshez közeli szakaszára illeszkednek (amely a kristályosodás korai szakaszát képviseli), majd hirtelen a trend megtörik és diagonálissá válik, amely a piroxén olivinnel való együttkristályosodását jelzi.

Ennek megfelelően, ha ki tudjuk zárni, hogy az olivinen és klinopiroxénen kívül más ásványfázis jelentôs mértékú kristályosodása is befolyásolta az olvadék (és így a vele egyensúlyt tartó olivin) összetételét, akkor az olivinek Fo, Ni-tartalma és a vele egyensúlyt tartó olvadék összetételének kiszámítása segítségével megbecsülhetjük az olivin \pm klinopiroxén frakcionációját.

Az alkáli bazaltos olvadék Mg-számát és a vele egyensúlyt tartó olivinek Fo-tartalmát elsősorban a két korai/uralkodó fenokristály fázis, az olivin és a klinopiroxén kristályosodása befolyásolja. Rajtuk kívül számottevő változást a Mg\#-ban amfibol kristályosodása vagy magnetit bekebelezése (és beolvasztása) tudna okozni. A bazaltos magma és a belőle kristályosodott olivinek Ni-tartalmának változását olyan ásványok képződése befolyásolja, amelyek nikkelre vonatkoztatott ásványolvadék-megoszlási együtthatója $\left(D_{N i}^{a s v-o l v}\right)$ nagyobb, mint egy. Ez az érték a magnetit esetében a legnagyobb, akár 30 is lehet (VILLEMANT et al. 1981), ettól nem sokkal marad el az olivin esetében mért felsô érték (25), míg klinopiroxének esetében 1-3, amfiboloknál pedig 0,6-3 között változik (HART \& DAVIS 1978, VILLEMANT et al. 1981, LEMARCHAND et al. 1987, LAUBIER et al. 2014).

A Kárpát-Pannon térség alkáli bazaltjainak csak kis részében fordul eló amfibol és ott is megakristályként (DEMÉNY et al. 2005), a modellezéshez amfibolmentes kốzeteket használtunk.

A magnetit akcesszórikus alapanyag fázis mindegyik vizsgált kőzetben, amely alig kimutatható Ni-koncentrációval jellemezhetô. Így ezek a magnetit mikrolitok aligha befolyásolhatták a náluk sokkal korábban képződött fenokristályok Ni-tartalmát, fóképp, hogy a bennük lévő kevés (200-700 ppm) nikkel mellett nagyon nagy mennyiségben kellett volna kristályosodniuk, amely viszont már az olvadék Mg\#-át drasztikusan megváltoztatta volna. Szintén jelentôs változást okozna, ha az olivinkristályokból erôs oxidáció hatására vas válik ki, és így a Fo-tartalmuk relatíve megnövekszik, ami nagyon meredek Fo-Ni-trendet eredményezne (CORTÉs et al. 2006). Ilyen jelenség a vizsgált alkáli bazaltok esetében nem fordul elő.

\section{A modellezés lépései}

A frakcionáció modellezést, két példán keresztül, az elektronikus mellékletben mutatjuk be.

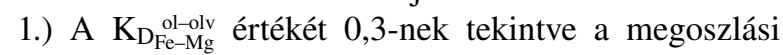
együttható és a teljes kôzet Mg\#-a alapján kiszámoltuk a bazalt teljes kôzet főelem-összetételével egyensúlyban lévő olivin Fo-tartalmát a következô módon:

$$
\text { Fo }(\mathrm{mol} \%)=100-(\mathrm{X} /(1+\mathrm{X}) \times 100) \text {, }
$$

ahol $\mathrm{X}=\left(\left[100 \times \mathrm{K}_{\mathrm{D}_{\mathrm{Fe}} \mathrm{Mg}}^{\text {ol-olv }}\right]-\left[\mathrm{Mg} \# \times \mathrm{K}_{\mathrm{D}_{\mathrm{Fe}-\mathrm{Mg}}}^{\text {ol-olv }}\right]\right) / \mathrm{Mg}$. Például ha a kőzet Mg\#-a 66 és a $\mathrm{K}_{\mathrm{D}_{\mathrm{Fe}-\mathrm{Mg}}}^{\text {ololv }}=0,3$, akkor az egyensúlyi olivin Fo-tartalma 86,61 mol\%.

A számoláshoz felhasznált teljeskőzet-összetételt a nyers adatokból a következô módon állítottuk elő: az izzítási veszteséget levontuk, majd ezt követően a $\mathrm{Fe}_{2} \mathrm{O}_{3}$-ként kifejezett összvastartalmat $\mathrm{Fe}^{3+} / \mathrm{Fe}^{2+}=0,15$ arány alkalmazásávával szétosztottuk $\mathrm{FeO}$-ra és $\mathrm{Fe}_{2} \mathrm{O}_{3}$-ra. $\mathrm{A} \mathrm{Ni}$ és $\mathrm{Cr}$ (ppm) értékeket átszámítottuk $\mathrm{NiO}$ és $\mathrm{Cr}_{2} \mathrm{O}_{3}(\mathrm{~m} / \mathrm{m} \%)$ értékekké.

Amennyiben a számolt egyensúlyi Fo-érték 0,1 mol\%-nál nagyobb mértékben eltért a kőzet legprimitívebb, Ni-ben és általában Fo-ben is - leggazdagabb olivinjének Fotartalmától, akkor a bazalt teljeskőzet főelem-összetételét úgy módosítottuk, hogy közöttük az egyensúly megvalósuljon. Ennek elérése céljából olivint adtunk hozzá vagy vontunk ki a teljeskőzet-összetételből 0,1 m/m\%-os adagokban, mindig a pillanatnyi olvadékkal lehetôleg egyensúlyt tartó, a kôzetben mért, valós olivinkristályok összetételét felhasználva. Amennyiben a legprimitívebb valós, mért olivin Fo-ben szegényebb, mint a kôzet összetételével egyensúlyt tartó hipotetikus kristály, a számoláshoz kizárólag a legprimitívebb olivin összetételét kell felhasználni. Az egyensúly eléréséhez szükséges olivin mennyisége $(\mathrm{m} / \mathrm{m} \%)$ megadja az adott bazalt és a legnagyobb Ni-tartalmú olivinnel egyensúlyt tartó olvadék közötti olivin-frakcionáció mértékét.

Például a BARC minta esetében a legnagyobb Ni-tartalmú olivin Fo-tartalma 87,8 mol\%, miközben a vizsgált bazalt 87,2 mol\% Fo-tartalmú olivinnel tart egyensúlyt, e kettő közötti különbséget $1,5 \mathrm{~m} / \mathrm{m} \%$ olivin frakcionációval magyarázhatjuk.

2.) A legnagyobb Ni-tartalmú mért olivinkristály Nikoncentráció értékét kiindulási pontként használva, HART \& DAvis (1978) kutatásai alapján változó (5-20) $D_{N i}^{o l-o l v}$ értékek mellett modelleztük az elsố pontban meghatározott mértékú olivin frakcionációval járó, az olivinek Ni-koncentrációjában bekövetkező változást. Amennyiben a teljeskőzetösszetétellel egyensúlyt tartó olivin Fo-tartalma kisebb, mint a legprimitívebb, Ni-ben leggazdagabb, mért olivinkristályé, úgy annak a kristálynak a Ni-tartalmát tekintjük a maximális értéknek, amelyhez képest a frakcionáció 
előrehaladtával az olivinek Ni-tartalma folyamatosan csökken. Ha a teljeskôzet-összetétel és a legtöbb nikkelt tartalmazó olivin közti egyensúly eléréséhez legalább 1 $\mathrm{m} / \mathrm{m} \%$ olivin frakcionáció szükséges, úgy jó eséllyel szúkíthetjük a $D_{N i}^{o l-o l v}$ valószínú tartományát. Ebben az esetben az olivin frakcionációs modellezés eredményeként kapott, a teljes kôzettel egyensúlyt tartó, hipotetikus olivinhez tartozó, 5-20 közötti $D_{N i}^{o l-o l v}$ értékek mellett lehetséges Nikoncentráció értékeket össze kell vetni azoknak a mért olivinkristályoknak a Ni-tartalmával, amelyek a fent említett, modellezéssel kapott hipotetikus olivinkristályhoz legközelebb állnak Fo-tartalom szempontjából. A számolt Nikoncentráció értékek közül elvetettük azokat, amelyek a mért és a modellezetthez leginkább hasonló Fo-tartalmú olivin koncentrációjától \pm 225 ppm-nél nagyobb mértékben eltértek, így szúkítve a bazaltok lehetséges $D_{N i}^{o l-o l v}$ értékét. A 225 ppm Ni-túréshatár biztosan nagyobb, mint az alkalmazott elektron-mikroszonda kimutatási és hibahatára.

Amennyiben a teljeskőzet-összetétel és a legprimitívebb mért olivinkristály összetétele azért nincs egyensúlyban, mert a kőzet az olivinhez képest túl sok magnéziumot tartalmaz, akkor a legprimitívebb mért olivin Ni-tartalmát az 1. pontban meghatározott mértékú olivin frakcionációhoz tartozó minimum Ni-értéknek tekinthetjük, és a $D_{N i}^{o l-o l v}$ értékét nem lehet szúkíteni, mivel csak a minimum olivin Nitartalomra lehet biztos feltételezésünk.

Pl. a BARC minta esetében a kezdeti $1,5 \mathrm{~m} / \mathrm{m} \%$ olivin frakcionációt - az olivinek Ni-koncentrációjára gyakorolt hatásának vizsgálata céljából - modelleztük 5 és $20 D_{N i}^{o l-o l v}$ értékek mellett. A megoszlási együttható függvényében a frakcionáció során az olivinek Ni-tartalma a legmagasabb 2437 ppm értékről 2291-1818 ppm-re csökkenne. A teljeskőzetösszetétellel egyensúlyt tartó olivin Fo-tartalma 87,2 mol\%, a mért olivinek esetében ehhez a Fo-értékhez tartozó Nikoncentráció 2043 ppm, azaz a modellezett Ni-koncentráció értékek közül az 1818-2268 ppm tartományt felhasználva a lehetséges $D_{N i}^{o l-o l v}$ értéket 5,7-20 tartományra szúkítettük.

3.) A bazaltok mért teljes kôzet fóelem-összetételéből - vagy ha az nem volt egyensúlyban a legmagasabb Nitartalmú olivinnel, akkor az első pontban kiszámolt elméleti teljeskőzet-összetételből - olivint kivonva, a kettes pontban meghatározott $D_{N i}^{o l-o l v}$ tartomány alapján, különböző Ni olivin-olvadék megoszlási együttható értékek mellett kiszámoltuk a kôzzetmintához tartozó elméleti olivin-frakcionációs Fo-Ni görbéket. Ennek elsô lépése a frakcionáció következtében az olvadékban - és így a vele egyensúlyt tartó olivinkristályokban a Mg-/Fo-tartalom csökkenésének becslése, mindig a pillanatnyi olvadékkal lehetőleg egyensúlyban lévő, mért olivinkristály összetételét vonva ki a kôzetből, $0,1 \mathrm{~m} / \mathrm{m} \%$-os lépésekben, összesen $15-20 \mathrm{~m} / \mathrm{m} \%$ olivin-frakcionációig. Ezt követően modelleztük az olivin frakcionációval járó, az olvadékban és a vele egyensúlyt tartó olivinkristályokban bekövetkező Ni-koncentráció csökkenést (Rayleigh frakcionációt feltételezve) a 3. pontban meghatározott értékek mellett, kiindulási pontnak a legmagasabb Ni-koncentrációjú olivinkristályt felhasználva.

4.) A primitív olivin összetételi adatok a Fo-Ni dia- gramon a kezdeti, tisztán olivin-frakcionáció következtében mindig exponenciális trendet rajzolnak ki (KAWABATA et al. 2011). A 3. pontban modellezett olivin Fo-Ni görbéket összevetettük a mért értékekkel, és amelyik illeszkedett a kezdeti - gyors Ni-csökkenéssel járó — trendre, azt kiválasztva megkaptuk a $D_{N i}^{o l-o l v}$ pontos értékét. Az illeszkedésvizsgálatnál a mért olivinkristályok közül a Fo-tartalom szempontjából a 75. percentilis felettiek összetételét vetettük össze a 3. pontban modellezett elméleti Fo-Ni görbék Fo-tartalom szempontjából megfelelő szakaszával és a legkisebb négyzetek módszerét alkalmazva választottuk ki a bazaltra jellemző $D_{N i}^{o l-o l v}$ értéket. A vizsgált kőzetek esetében az olivinek Fo-tartalma alapján a 75. percentilis 77,3885,63 mol\% Fo-tartalom között, a $D_{N i}^{o l-o l v}$ értéke 8-16 között változik. Kivételt képez a „BRE” minta, ahol olyan kevés olivin esik a 75. percentilis fölé és olyan magas az olivinkristályok átlagos Fo-tartalma, hogy a Fo $\geq 84 \mathrm{~mol} \%$ olivineket vettük figyelembe az illeszkedésvizsgálatnál.

5.) Az elméleti, tisztán olivin-frakcionációs görbét a mért olivin összetételi adatokhoz hasonlítva megvizsgáltuk, hogy azok teljesen illeszkednek-e a görbére, vagy pedig egy ponton eltérnek tőle, és az exponenciális helyett lineáris trendet rajzolnak ki. Ennek a görbének a felsô kiindulópontja (a $0 \mathrm{~m} / \mathrm{m} \%$ olivin-frakcionáció pontja) vagy a legnagyobb Ni-tartalmú olivin összetételével egyezik meg (ha annak Mg\#-a nagyobb vagy egyenló a teljeskőzetösszetétel alapján számolt egyensúlyi olivinével) vagy egy számolt, hipotetikus olivinével azonos (ha a legnagyobb Ni-tartalmú olivin Mg\#-a kisebb a teljeskőzet-összetételből számolt egyensúlyi olivinénél).

6a) Amennyiben teljes mértékben illeszkedtek a mért olivin adatok a számolt exponenciális trendre, akkor egyszerúen a legkisebb Fo- és Ni-tartalmú olivinek alapján kiszámítottuk a magmából frakcionálódott olivin mennyiségét (gyakorlatilag csak le kell olvasni a görbéről). Ebben az esetben, itt a frakcionáció-számolás véget is ért és a 9. lépésre ugrunk.

6b) Amennyiben a mért olivin adatok által kirajzolt trend egy exponenciális és egy lineáris szakaszra bontható, úgy először kiszámoltuk a kezdeti, tisztán olivin frakcionáció mértékét (addig a pontig, ahol a mért adatok elhagyják az exponenciális görbét).

7.) Az olivin + klinopiroxén együttes kristályosodásának becslése. Elsőként a $6 \mathrm{~b}$ pontban írt korai olivin-frakcionációs szakasz végét jelentô olivin-összetételhez kiszámoltuk az egyensúlyt tartó olvadék összetételét az 1. és 4. pontokhoz hasonló módon. A továbbiakban ezt az olvadék-összetételt (,köztes olvadék”) használtuk fel a modellezéshez. Frakcionációs együttkristályosodást feltételeztünk, valamint a számolásnál a 3. pontban kiválasztott $D_{N i}^{o l-o l v}$ értéket és konstans $D_{N i}^{c p x-o l v}$ értéket (2,8 - LAUBIER et al. 2014) használtunk. A lineáris olivin $\mathrm{Fo}-\mathrm{Ni}$ trend elején és végén szereplő $\mathrm{Ni}$ koncentráció értékeket vettük alapul a számoláshoz, és az e kettő között történt ásvány-olvadék Ni-frakcionációt különböző olivin/piroxén arányok mellett számoltuk ki. A számolásnál az olivin mennyiségét $0,1 \mathrm{~m} / \mathrm{m} \%$-os lépésenként változtattuk a hozzá szükséges klinopiroxén-mennyiséggel 
kiegészítve. Például ha a lineáris trenden a Ni-koncentráció 1100 ppm-ról 300 ppm-re csökken, a $D_{N i}^{o l-o l v}$ pedig 12 , akkor a Ni-tartalom változása modellezhetô $11,2 \mathrm{~m} / \mathrm{m} \%$ olivin vagy $51,4 \mathrm{~m} / \mathrm{m} \%$ piroxén vagy a két ásvány együttes, a fenti értékeknél kisebb mértékú frakcionációjával. A „köztes olvadék" összetételéből a megfelelő mennyiségû olivint és klinopiroxént kivonva minden egyes olivin/piroxén $\mathrm{Ni}$ frakcionációs arányhoz kiszámoltuk az egyensúlyt tartó olvadék összetételét, amelyből az azzal egyensúlyban lévő olivin Fo-tartalmát is ki tudtuk számolni. Amennyiben a számolt Fo-tartalom megegyezett a lineáris trend Niszegény végén található olivinek Fo-koncentrációjával, akkor az adott olivin/piroxén arányt (és mennyiséget) fogadtuk el, mint az együtt kristályosodásra jellemző frakcionációs érték.

8.) A 6 b és a 7. pontban megkapott olivin, illetve olivin + piroxén mennyiségek összegzésével kiszámoltuk a kôzetre jellemzô teljes olivin- és klinopiroxén-frakcionáció mértékét. A frakcionáció modellezést - az itt bemutatott lépések szerint - az elektonikus mellékletben részletezzük.

9.) A szülő- (primitív) magma főelem-összetételének becslése céljából a frakcionációs számolások során meghatározott mennyiségú klinopiroxént és olivint adtunk a teljeskőzet-összetételhez. A hozzáadott ásványok átlagos összetételét és a számolt primitívmagma-összetételeket a III. táblázat tartalmazza.

10.) A kapott primitívmagma-összetételi adatokat összevetettük a LEE et al. (2009) tanulmányában publikált kalkulátor által a teljeskôzet-adatokból számolt primitív olvadékok összetételével (III. táblázat). Minden olyan kôzet esetében, ahol jelentôs klinopiroxén-frakcionációt mutattunk ki, a LeE et al. (2009) módszert alkalmazva a sajátunkhoz képest jelentősen magasabb $\mathrm{MgO}$-tartalmú szülő(primitív) magmát kaptunk, míg a tisztán olivin-frakcionált

\section{III. táblázat. A primitívolvadék-összetétel számításokhoz felhasznált adatok és a kapott eredmények \\ Table III. Mineral compositions used for primitive melt calculation and the results of calculation}

IIIa táblázat. A teljeskőzet-összetételhez hozzáadott olivin mennyisége és átlagos összetétele $(\mathrm{m} / \mathrm{m} \%)$

Table IIIa. The amount and average composition of olivine added to the bulk rock composition (wt.\%)

\begin{tabular}{|c|c|c|c|c|c|c|c|}
\hline Minta & SAG & BRE & BARC & ST & SAN & KS & CSOM \\
\hline+ ol & 19,62 & 12,40 & 23,19 & 7,44 & 16,53 & 5,40 & $*$ \\
\hline $\mathrm{Si}_{2}$, & 39,47 & 40,09 & 39,24 & 40,01 & 39,31 & 39,93 & 39,58 \\
\hline $\mathrm{TiO}$, & & 0,00 & 0,00 & 0,04 & 0,00 & 0,01 & 0,00 \\
\hline $\mathrm{Al}, \mathrm{O}_{\uparrow}$ & & 0,01 & 0,05 & 0,03 & 0,03 & 0,03 & 0,02 \\
\hline $\mathrm{Fe} 0$ & 16,42 & 11,74 & 17,66 & 13,05 & 16,73 & 14,74 & 15,13 \\
\hline $\mathrm{Mn} 0$ & 0,25 & 0,24 & 0,35 & 0,20 & 0,24 & 0,25 & 0,41 \\
\hline $\mathrm{Mg} 0$ & 43,41 & 46,76 & 42,22 & 46,23 & 43,22 & 44,53 & 44,49 \\
\hline $\mathrm{Ca} 0$ & 0,28 & 0,27 & 0,28 & 0,21 & 0,24 & 0,27 & 0,20 \\
\hline $\mathrm{P}, \mathrm{O}_{s}$ & & & 0,00 & 0,00 & 0,00 & 0,02 & 0,00 \\
\hline $\mathrm{Ni} 0$ & 0,18 & 0,24 & 0,19 & 0,23 & 0,18 & 0,19 & 0,16 \\
\hline $\mathrm{Cr}, \mathrm{O}_{\uparrow}$ & & 0,04 & & & 0,05 & 0,02 & 0,01 \\
\hline
\end{tabular}

*A csomádi modellezésnél felhasznált olivinek átlagos összetétele.

Average composition of olivines from the Csomád crystal clots used in the modeling.
IIIb. táblázat A teljeskőzet-összetételhez hozzáadott klinopiroxén mennyisége és átlagos összetétele $(\mathrm{m} / \mathrm{m} \%)$. A SAG, BRE és BARC minták esetében nem volt szükség cpx hozzáadására

TableIIIb. The amount and average composition of clinopyroxene added to the bulk rock composition (wt. \%). There was no need for clinopyroxene addition to the samples of SAG, BRE and BARC

\begin{tabular}{|c|c|c|c|}
\hline Minta & ST & SAN & KS \\
\hline$+\mathrm{cpx}$ & 31,12 & 5,41 & 20,69 \\
\hline $\mathrm{SiO}$, & 50,67 & 48,70 & 50,08 \\
\hline $\mathrm{TiO}$, & 0,95 & 1,86 & 1,26 \\
\hline $\mathrm{Al}_{2} \mathrm{O}_{3}$ & 3,77 & 4,69 & 3,65 \\
\hline $\mathrm{Fe}, \mathrm{O}_{3}$ & 3,07 & 3,19 & 2,97 \\
\hline $\mathrm{Fe} 0$ & 2,70 & 4,27 & 2,70 \\
\hline $\mathrm{MnO}$ & 0,13 & 0,13 & 0,14 \\
\hline $\mathrm{Mg} 0$ & 14,99 & 14,00 & 14,95 \\
\hline $\mathrm{CaO}$ & 22,56 & 22,40 & 22,89 \\
\hline $\mathrm{Na}, 0$ & 0,63 & 0,40 & 0,47 \\
\hline $\mathrm{NiO}$ & & & 0,02 \\
\hline $\mathrm{Cr} \mathrm{O}_{3}$ & 0,35 & 0,03 & 0,43 \\
\hline
\end{tabular}

IIIc. táblázat A tanulmányban közölt modellezéssel számolt primitívmagma-összetételek

Table IIIc. Calculated primitive magma compositions based on our model

\begin{tabular}{|c|c|c|c|c|c|c|}
\hline Minta & SAG & BRE & BARC & ST & SAN & KS \\
\hline $\mathrm{SiO}$, & 47,83 & 44,13 & 45,06 & 46,40 & 48,06 & 46,29 \\
\hline $\mathrm{TiO}$, & 1,71 & 2,15 & 1,37 & 1,93 & 1,77 & 2,00 \\
\hline $\mathrm{Al}_{2} \mathrm{O}_{3}$ & 12,74 & 11,53 & 12,31 & 10,76 & 12,63 & 11,88 \\
\hline $\mathrm{Fe}, \mathrm{O}_{3}$ & 0,95 & 1,21 & 0,93 & 1,81 & 1,09 & 1,57 \\
\hline $\mathrm{FeO}$ & 9,54 & 9,52 & 10,28 & 7,75 & 9,14 & 7,74 \\
\hline $\mathrm{MnO}$ & 0,16 & 0,18 & 0,21 & 0,16 & 0,16 & 0,17 \\
\hline $\mathrm{MgO}$ & 14,98 & 15,39 & 16,90 & 12,56 & 14,18 & 11,65 \\
\hline $\mathrm{CaO}$ & 6,69 & 8,85 & 7,35 & 13,44 & 7,69 & 11,86 \\
\hline $\mathrm{Na}, 0$ & 2,68 & 3,54 & 3,02 & 2,95 & 2,63 & 3,37 \\
\hline $\mathrm{K}, 0$ & 1,58 & 1,51 & 1,47 & 1,37 & 1,53 & 1,89 \\
\hline $\mathrm{P}, \mathrm{O}_{5}$ & 0,39 & 0,67 & 0,37 & 0,53 & 0,38 & 0,66 \\
\hline $\mathrm{NiO}$ & 0,06 & 0,05 & 0,06 & 0,02 & 0,05 & 0,03 \\
\hline $\mathrm{Cr}, \mathrm{O}_{2}$ & 0,04 & 0,05 & 0,04 & 0,02 & 0,05 & 0,12 \\
\hline $\mathrm{Mg} \#$ & 73,68 & 74,24 & 74,55 & 74,30 & 73,45 & 72,85 \\
\hline $\mathrm{Mg} \#=100 \times \mathrm{Mg}^{\prime}\left(\mathrm{Mg}^{2} \mathrm{Fe}^{2+}\right)$ &
\end{tabular}

IIId. táblázat. A primitívmagma-összetétel modellezése LEE et al. (2009) alapján

Table IIId. Calculated primitive magma compositions based on LEE et al. (2009) model

\begin{tabular}{|c|c|c|c|c|c|c|}
\hline Minta & SAG & BRE & BARC & ST & SAN & KS \\
\hline $\mathrm{SiO}$, & 48,86 & 44,93 & 46,49 & 44,55 & 48,27 & 45,34 \\
\hline $\mathrm{TiO}_{2}$ & 1,80 & 2,13 & 1,54 & 1,50 & 1,82 & 1,91 \\
\hline $\mathrm{Al}_{2} \mathrm{O}_{1}$ & 13,37 & 11,43 & 13,92 & 11,25 & 12,20 & 12,26 \\
\hline $\mathrm{Fe}_{2} \mathrm{O}_{3}$ & 0,42 & 0,50 & 0,44 & 0,44 & 0,44 & 0,44 \\
\hline $\mathrm{Fe} 0$ & 9,19 & 10,33 & 9,21 & 10,94 & 9,91 & 10,06 \\
\hline $\mathrm{MnO}$ & 0,12 & 0,15 & 0,15 & 0,13 & 0,12 & 0,14 \\
\hline $\mathrm{Mg} 0$ & 14,78 & 16,75 & 14,90 & 17,62 & 15,96 & 16,29 \\
\hline $\mathrm{CaO}$ & 6,96 & 8,74 & 8,24 & 7,89 & 7,08 & 7,83 \\
\hline $\mathrm{Na}, 0$ & 2,81 & 3,50 & 3,41 & 4,07 & 2,82 & 3,61 \\
\hline $\mathrm{K}, 0$ & 1,66 & 1,49 & 1,67 & 1,60 & 1,35 & 2,09 \\
\hline $\mathrm{Mg} \#$ & 74,13 & 74,28 & 74,26 & 74,18 & 74,15 & 74,26 \\
\hline
\end{tabular}


magmák esetében a két módszer által számolt primitív magmák hasonló összetételúek.

\section{A modellezés korlátai}

1.) A bemutatott modell segítségével csak abban az esetben tudjuk a klinopiroxén frakcionációját jelezni és megbecsülni, ha az olivinnel együtt kristályosodott, és ezáltal befolyásolta az olvadékkal egyensúlyt tartó olivin Ni-tartalmát. SMITH et al. (2008) bemutatták, hogy alkáli bazaltos magmák esetében - az olivint megelőzően — már a köpenylitoszférában bekövetkezhet ún. kriptikus klinopiroxén-frakcionáció. E folyamat az olivinkristályok összetételében nem tükröződik, így az általunk leírt frakcionációbecslés a kriptikus piroxénkristályosodás meghatározására nem alkalmas.

2.) Az olivin és klinopiroxén együttes frakcionációbecslése során a rendszerben állandó paraméternek paraméternek tekintettük a $D_{N i}^{o l-o l v}$ és $D_{N i}^{c p x-o l v}$ értékét, előbbit a modellezés 4 . pontjában leírt módon meghatározva, utóbbit pedig LAUBIER et al. (2014) alapján 2,8-nek tekintve. Változónak tekintjük a kristályosodott klinopiroxén és olivin mennyiségét, a két ásvány arányát és ebből fakadóan a köztes olvadékból számolt végsô magmaösszetételt is. Mivel a rendszerben több változó paraméterrel számolhatunk, a két ásvány együttes frakcionációjának e pontban leírt becslése nehézkes, jelen tanulmányban csupán néhány mintán végeztük el a számolásokat. Gyorsabb és minden bizonnyal precízebb módszer lenne az olivinfrakcionációs trendre nem illeszkedô olivinkristályok legkisebb és legnagyobb Fo- és Ni-tartalma által kijelölt diagramterületen, a lehetséges $D_{N i}^{o l-o l v}$ és $D_{N i}^{c p x-o l v}$ értékek alapján, pl. Monte Carlo-szimulációt végezni, így távlati célunk ennek kivitelezése a frakcionáció-becsló módszer fejlesztése szempontjából.

3.) Még ha a bazalt és olivinkristályai üdék is, a kôzet nem tartalmaz olivin- vagy Ni-gazdag magnetit xenokristályokat és jelentôs mértékben csak olivin- és klinopiroxénfrakcionáció hatott a primitív magmák összetételére, akkor sem tudunk minden esetben megbízható frakcionációs modellezést végezni. Előfordulhat ugyanis, hogy a bazaltban megjelenő legprimitívebb olivinek is olyan kis Fo- és Nitartalmúak, hogy nem lehet teljes bizonyossággal meghatározni a $D_{N i}^{o l-o l v}$ értékét, és így a modellezés sem vihető végig. Ez esetben legfeljebb más, petrográfiailag és teljeskôzetösszetétel szempontjából hasonló kôzetek modellezéséhez hasonlíthatjuk a vizsgálandó olivineket, és ez alapján adhatunk becslést a $D_{N i}^{o l-o l v}$ közelítő értékére. Számos olyan alkáli bazalt lávakőzet ismert a Kárpát-Pannon térségben, amelyek legprimitívebb olivinkristályai is csak 77-84 mol\% forsteritet tartalmaznak, mint pl. a Szent-György-hegy, a Haláp, (EMBEY-IszTin \& Dobosi 2007), a Badacsony, a Hegyestû, a Kovácsi-hegy vagy Uzsabánya alkáli bazaltja (s.l.) (EMBEY-IsZTiN et al. 1993a, b; SÁGI 2008). Ezek közül az uzsai trachibazalt példáján mutatjuk be ezt a problémát (l. később 5. ábra, a). A kôzet petrográfiailag az 1-es típusba tartozik, ásványos és kémiai összetételében nagyon hasonlít a ság-hegyi mintára (SAG), viszont magnéziumban leggazdagabb olivinkristályának Fo-tartalma mindössze 84,1 mol\%, a legnagyobb Ni-koncentrációjú kristályé (1430ppm Ni) 81,8 mol\%. A teljeskőzet-összetétellel egyensúlyt tartó oliviné pedig 85,6 mol\% lenne. Ezek az értékek egyértelmúen kisebbek, mint a többi vizsgált alkáli bazalt esetében mért megfelelő koncentráció értékek. Az uzsai kôzettel egyensúlyt tartó olivin Fo-tartalma sokkal kisebb, mint a többi bazalt esetében a frakcionációs számolás kiindulópontjaként alkalmazott valós vagy számolt olivineké (4. ábra). HerzBerg (2011) szerint a fertilis peridotit olvadékával egyensúlyt tartó olivinek Fo-tartalma 89-93 mol\%, a belőlük olivin-frakcionáció során képződött, $8-13$ m/m\% MgO-tartalmú magmák legnagyobb Mg-tartalmú olivinkristályainak Fo-tartalma pedig 86-89 mol\%. Mindezek alapján kijelenthetô, hogy 1.) az uzsai trachibazalt összetétele nem képviseli a primitív (szülő-) magmát, és 2.) a legmagasabb Fo- és Ni-tartalmú olivin fenokristályai jóval kevesebb magnéziumot tartalmaznak, mint a hasonló összetételú alkáli bazaltok legprimitívebb példányai. A magasabb Fo- és Ni-tartalmú olivinek hiányának kérdése egyelôre még nem tisztázott, de feltételezzük, hogy a magmaképződés és frakcionáció ez esetben is a többi vizsgált, 1es típusú bazaltéhoz hasonló lehetett, így minden bizonnyal a megfigyelteknél jóval magasabb Fo- és Ni-koncentrációjú kristályoknak is képződniük kellett. E feltételezés alapján összehasonlítottuk az uzsai olivin-összetételi adatokat három másik kőzet frakcionáció modellezésével (5. ábra). Az 1-es típusba tartozó BRE minta frakcionációs görbéjéhez $\left(D_{N i}^{o l-o l v}=10\right)$ képest az eltérés jelentôs, amely irreálisan nagymértékú klinopiroxén-frakcionáció esetén valósulhatna meg (5. ábraa).

Annak ellenére, hogy az UZSA minta az 1-es típusú alkáli bazaltok közé tartozik, tartalmaz elenyészô mennyiségú klinopiroxén fenokristályt, ezért összevetettük a 2-es típusú alkáli bazalt (SAN) frakcionáció modellezésével is (5. ábra b). A hasonlóság jóval nagyobb, mint az előző esetben, azonban még így is olyan mértékú olivin + klinopiroxén együttkristályosodással lehetne csak az uzsai olivinek frakcionációját modellezni, amely mintegy 0,4 piroxén/ olivin arányt eredményezne.

A SAG minta olivin-frakcionációs modellgörbéjére nagyon jól illeszkednek az uzsai olivinek (5. ábra c). Ha feltételezzük, hogy a két kőzet hasonló szülőmagmából eredeztethetô, akkor az UZSA minta esetében $8,5 D_{N i}^{o l-o l v}$ érték mellett mintegy $18 \mathrm{~m} / \mathrm{m} \%$-os olivin-frakcionációt becsülhetünk.

Az olivinek Ni- és Fo-tartalma szempontjából konkrét, a modellezésre alkalmas tartományt nem tudunk kijelölni. Empirikus úton, a részletesen vizsgált, illetve az e pont elején említett alacsony maximális Fo-és Ni-koncentrációjú olivinkristályokat tartalmazó bazaltok alapján arra következtethetünk, hogy a modellezés annál biztosabb alapokon áll, minél inkább meredek Fo-Ni trend jellemzi az olivinpopuláció Fo-ben leggazdagabb csoportját (75. percentilis feletti értékek), amely lehetóleg a 2500-1200 ppm Ni- és a 89-82 mol\% Fo-tartományba esik. 

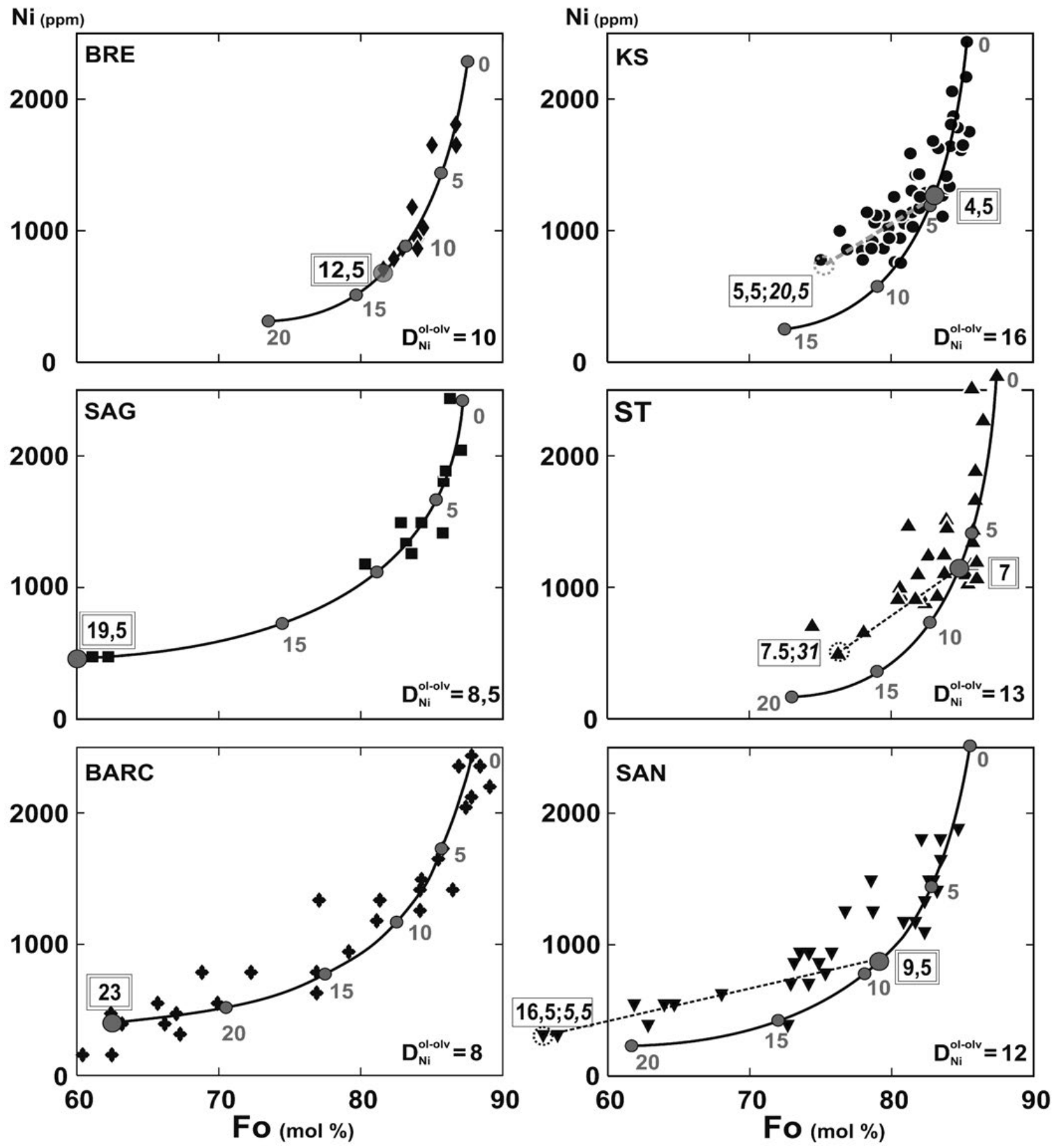

4. ábra. Az olivin-piroxén frakcionáció modellezése

A bal oldalon az 1-es típusú alkáli bazaltok olivinjeinek összetételét ábrázoltuk, a jobb oldalon pedig a 2-es (SAN) és a 3-as típusú (KS, ST) kőzetekben lévőkét. A fekete folytonos vonal a teljeskőzet-összetétel felhasználásával és a diagramokon feltüntetett $D_{N i}^{o l-o l v}$ értékkel modellezett olivin frakcionáció görbéje. Kezdőpontja ( 0 $\mathrm{m} / \mathrm{m} \%$ ) megegyezik a legnagyobb mért Ni-tartalmú olivin összetételével, vagy ha annak Mg\#-a nem áll egyensúlyban a teljeskőzet-összetétellel, akkor a kettőből számított értékkel (Részletes magyarázat az 'Olivin-és klinopiroxén frakcionáció modellezése' c. fejezetben és az elektronikus mellékletben.).

Tisztán olivin frakcionáció becslése (bal oszlop). A folytonos fekete görbe mentén szürke számmal jeleztük a frakcionáció növekvő mértékét, a kettős keretben lévő szám mutatja az adott bazaltra számolt olivin frakcionációt ( $\mathrm{m} / \mathrm{m} \%)$.

Olivin + klinopiroxén frakcionáció (jobb oszlop). Addig a pontig, amíg a mért olivin összetételek illeszkednek a tisztán olivin frakcionációs görbére, a modell nem különbözik a bal oldalitól. Utána viszont a mért értékek - az olivin + klinopiroxén együttkristályosodása révén - egy diagonális egyenesre illeszkednek (szaggatott vonal). A szaggatott vonal jobb végénél kettős keretben lévő szám mutatja a kezdeti, tisztán olivin frakcionáció mértékét, a vonal bal végénél a keretben lévő két szám pedig a teljes olivin- és klinopiroxén frakcionációt (utóbbi dőlt számmal)

Figure 4. Modeling of olivine- and clinopyroxene fractionation

Olivines from the $1^{\text {st }}$ type of alkaline basalts are on the left, from the $2^{\text {nd }}(S A N)$ and $3^{\text {rd }}$ type $(K S, S T)$ on the right

Black continuous curves show calculated compositions of olivines during an olivine-only fractionation from the given alkaline basaltic melt (applied values $D_{N i}^{\text {ol-liq }}$ are indicated on each diagram). Its upper starting point ( 0 wt. \%) matches with the composition of the most Ni-rich olivine measured in the sample, or if that olivine has too low Mg\# being in equilibrium with the host rock then starting point represents an artificial olivine composition calculated from the host rock and the most Ni-rich olivine.

Olivine-only fractionation (left column): grey numbers along the black continuous curve indicate the rising degree of olivine fractionation, numbers in double frame show the total amount of olivine fractionation for each sample (both are wt. \%).

Olivine + clinopyroxene fractionation (right column): until the measured olivine compositions are fitting to the black continuous curve the model is the same as in the left side. From a given point in the Fo-Ni plot measured olivine data points will fit to a diagonal linear trend (dashed line) because of co-crystallization of olivine and clinopyroxene. In a double frame at the right end of this line a number indicates the amount of olivine that was crystallized in the early, olivine-only fractionation phase. The total amounts of olivine and clinopyroxene fractionation (latter one with italic numbers) are shown in a single frame at the left end of the dashed line (both are wt. \%) 

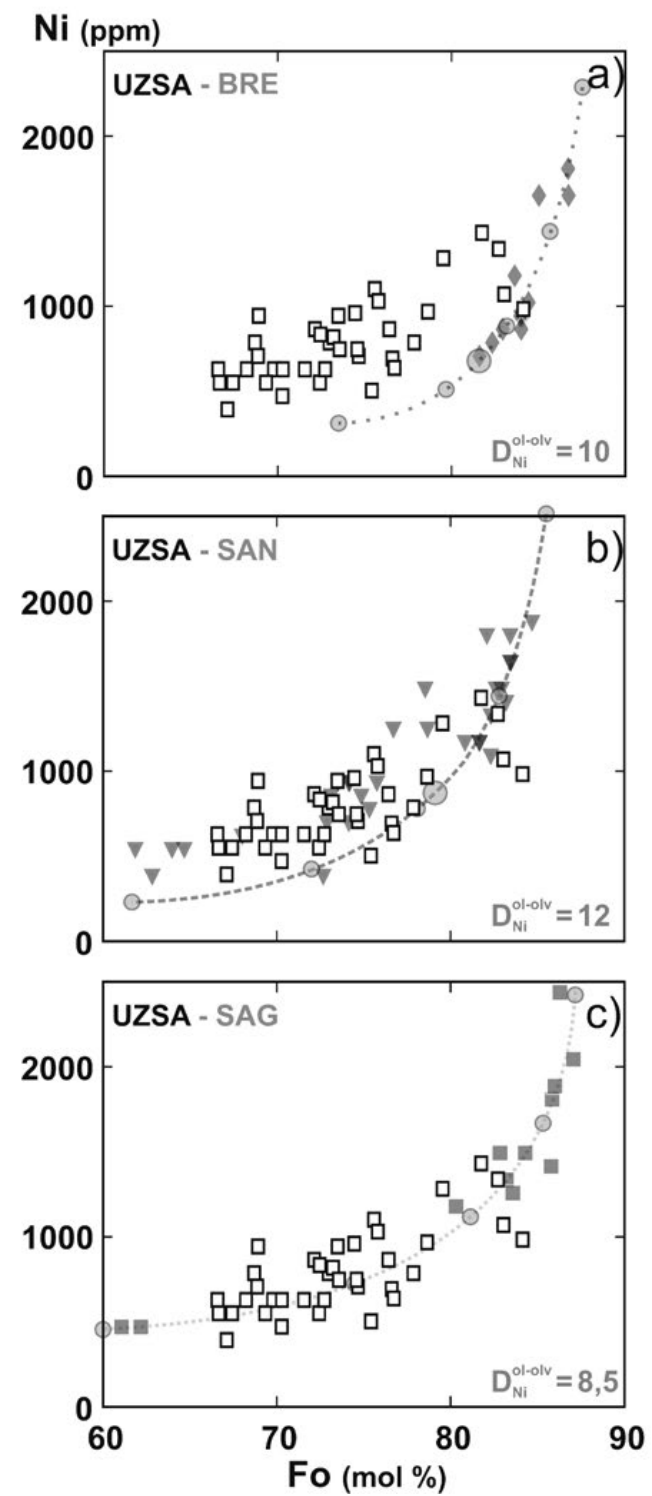

\section{A modellezés eredményei és azok értékelése}

\section{Tisztán olivin-frakcionált magmák}

Három minta (BRE, SAG, BARC) esetében az olivinek a Fo-Ni diagramon jól illeszkednek egy tisztán olivinfrakcionációs görbére, a megadott sorrendben csökkenó $D_{N i}^{o l-o l v}$ szerint, amelynek értéke 10 és 8 között változik. Ebben a sorrendben nő a frakcionálódott olivin mennyisége 12,5-tól $23 \mathrm{~m} / \mathrm{m} \%$-ig (4. ábra). Az így kiszámolt olivinmennyiségeket a teljeskőzet-összetételhez adva átlagosan 74,2 Mg-számú primitív olvadékokat kaptunk (III. táblázat).

\section{Olivin- és klinopiroxén-frakcionált magmák}

A másik három minta (KS, ST, SAN) esetében az olivinek kezdetben az exponenciális görbét követik, majd azt elhagyva egy lineáris trendet rajzolnak ki (4. ábra). A minták sorrendje szerint csökken a becsült $D_{N i}^{o l-o l v}$ értéke $16-$ ról 12-re, és ennek megfelelően ugyanebben a sorrendben
5. ábra. Frakcionáció modellezés elégtelen olivinösszetételi adatsor esetén Amennyiben a vizsgált kőzetben a legmagasabb Ni-tartalmú olivin, valamint a teljeskőzetösszetétellel egyensúlyt tartó olivin Fo-tartalma is $\leq \sim 85 \mathrm{~mol} \%$, a modellezés bizonytalanná válik, mivel a kezdeti, gyors olivin-frakcionációs szakasz hiányában a $D_{N i}^{o l-o l v}$ értékét nem tudjuk megbecsülni és az elméleti olivin-frakcionációs görbét sem tudjuk elkészíteni. Ilyenkor geokémiailag és petrográfiailag hasonló kőzetek alapján végzett modellezés eredményével összevetve közelítő becslést adhatunk a magma frakcionációjára vonatkozóan.

A diagramokon egy olivin-fíros alkáli trachibazalt (UZSA) olivin adatait (fehér négyzetek) hasonlitottuk össze a tanulmányban vizsgált három másik alkáli bazaltos kőzet frakcionáció modellezésével. Az olivin frakcionáció modellezése során alkalmazott $D_{N i}^{o l-o l v}$ értéket minden diagramon feltüntettük

a) A Putikov vršsok bazanitjának (BRE) olivin-frakcionációs görbéjéhez képest az uzsai olivinek akkora eltérést mutatnak, amit csak irreálisan nagymértékủ klinopiroxén kristályosodással lehetne magyarázni, ami, ha egyáltalán lehetséges lenne, akkor egy klinopiroxén-fíros bazalthoz vezetne

b) Az olivin-piroxén-fíros sanovițai alkáli trachibazalt (SAN) frakcionációs modelljéhez viszonyitva már nagyobb a hasonlóság, azonban nincs olyan olivin/piroxén arányú frakcionáció, amellyel a fejlett uzsai olivinek Fo- és Ni-tartalma egyszerre modellezhetők lennének (Fo: 70-67 mol\%, Ni: 500 ppm).

c). A ság-hegyi bazalt (SAG) olivin-frakcionációs görbéjére jól illeszkednek az uzsai olivinek. Ha feltételezzük, hogy az uzsai trachibazalt a ság-hegyihez hasonló olvadékból képződött, és csak a nagy Fo-tartalmú olivinek hiányoznak belőle, akkor a SAG mintához tartozó frakcionációs görbe alapján mintegy $18 \mathrm{~m} / \mathrm{m} \%$-os olivin frakcionációval számolhatunk az UZSA esetében. A két kőzet nagyon hasonló főelem-összetétele és Mg\#a alapján e becslés reálisnak tủnik

Figure 5 Fractionation modeling based on unsatisfactory amount of olivine data. If the olivine with highest $\mathrm{Ni-content} \mathrm{and} \mathrm{the} \mathrm{equilibrium} \mathrm{olivine} \mathrm{calculated} \mathrm{from} \mathrm{the} \mathrm{bulk} \mathrm{rock}$ has $\leq \sim 85$ mol\% Fo-content the modeling could be uncertain. The lack of the first rapid olivine fractionation period makes the calculation of the $D_{N i}^{o l-l i q}$ and the hypothetical olivine-only fractionation curve impossible. In this case it is worth to compare olivine data with the fractionation modeling of rock samples with similar geochemical and petrographical characteristics to get at least an approximate estimate of melt fractionation.

Olivine data (white squares) from an olivine phyric alkaline trachybasalt (UZSA) are compared to the fractionation modeling of three other alkaline basaltic rocks from the Carpathian-Pannonian Region. The applied values $D_{N i}^{\text {ol-liq }}$ are indicated in each diagram.

a) Compared to the olivine fractionation curve of the basanite from Putikov vŕšk (BRE) olivines from UZSA have a so huge difference which could be explained only with an unrealistically high degree of clinopyroxene fractionation. Even if that would be possible it would cause a pyroxene rich basalt.

b) There seem to be similarities with the fractionation modeling of the olivine-pyroxene phyric alkaline trachybasalt of Sanovita (SAN), however not a single olivine/pyroxene ratio could led to olivines with the Fo-and Ni-content like the primitive ones from UZSA sample (Fo: 70-67 mol\%, Ni: $500 \mathrm{ppm}$ )

c) Olivines from UZSA are fitting well to the fractionation curve of SAG, an olivine phyric alkaline trachybasalt. Assuming a similar parental melt for both basalts and the lack of highFo olivines from the UZSA sample an amount of $18 \mathrm{wt}$ \% olivine fractionation is probable. The two rock samples have a very similar main elements composition and Mg\# which makes the fractionation estimation realistic

nő a tisztán olivin frakcionációs szakaszban kristályosodott olivinek mennyisége is. Az olivin + piroxén együttkristályosodás szakaszában képződött olivinek aránya a legkisebb $D_{N i}^{o l o l v}$ értékú mintánál (SAN) a legnagyobb, ez hasonlít a leginkább a tisztán olivint kristályosító olvadékokhoz. Az így kiszámolt olivin és klinopiroxén mennyiségeket a teljeskőzet-összetételhez adva átlagosan 73,5 Mg-számú primitívolvadékokat kaptunk (III. táblázat).

\section{A modellezés realitásának vizsgálata}

A modell alapján azok az olvadékok, amelyekből klinopiroxén is kristályosodik, nagyobb $D_{N i}^{o l-o l v}$ értékkel jellemezhetôk. HART \& DAVIS (1978) kísérletei alapján a bazaltos magma hőmérséklete és MgO-tartalma fordítottan arányos a $D_{N i}^{o l-o l v}$ értékkel. $5-10 \mathrm{~m} / \mathrm{m} \% \mathrm{MgO}$-tartalmú és $1250{ }^{\circ} \mathrm{C}$ hőmérsékletú olvadékra a nikkel olivinolvadék megoszlási együttható értéke 14-23, ugyanez a megoszlási együttható $10-17 \mathrm{~m} / \mathrm{m} \%$ MgO és $1350{ }^{\circ} \mathrm{C}$ mellett pedig már csak 7-12. $\mathrm{Az}$ általunk számolt primitív magmák összetétele és a 
becsült értékek ezzel összhangban vannak. A kizárólag olivin-frakcionált olvadékokból (BRE, SAG, BARC) számolt primitív magmák $15-17 \mathrm{~m} / \mathrm{m} \%$ MgO-t tartalmaznak, a $D_{N i}^{o l-o l v}$ becsült értéke pedig 8-10. A klinopiroxént is kristályosító olvadékokból (KS, ST, SAN) számolt primitív magmák jellemzően 11-14 m/m\% MgO-t tartalmaznak, a $D_{N i}^{o l o l v}$ értéke pedig 12-16.

Számításaink eredménye egybevág a petrográfiai megfigyeléseinkkel is. Az 1-es típusú (olivin-fíros) alkáli bazaltok (BRE, SAG, BARC) esetében a modell csak olivin frakcionációt mutatott ki. A 2-es típust képviselő SAN minta javarészt olivin fenokristályokat tartalmaz, de emellett mintegy 20-25\% klinopiroxén is megjelenik. Frakcionáció-számolásunk eredménye $16,5 \mathrm{~m} / \mathrm{m} \%$ olivin és 5,5 $\mathrm{m} / \mathrm{m} \%$ klinopiroxén, amely az utóbbi ásvány 25\%-os arányát jelenti. A 3-as típusú alkáli bazaltokban (ST, KS) a klinopiroxén a domináns fenokristály mintegy 70-80\%-os aránnyal. Modellezésünk szerint ezeknél a mintáknál az olivin- és klinopiroxén-frakcionáció mértéke 7,5 és 31 $\mathrm{m} / \mathrm{m} \%$ (ST), illetve 5,5 és $20,5 \mathrm{~m} / \mathrm{m} \%$ (KS), ami $80,5 \%$-os (ST) és 79\%-os (KS) klinopiroxén aránynak felel meg.

Modellezésünk eredményeinek további ellenőrzése céljából a kiindulási teljeskőzet fôelem-összetételi adatokat felhasználva primitívmagma-összetétel modellezést is végeztünk a LEE et al. (2009) által készített kalkulátorral (III. táblázat). Az így kapott primitív magmák Mg\#-a hasonló ahhoz, amelyet az általunk kidolgozott modellel számoltunk, habár az egyes minták sokkal kisebb eltérést mutatnak egymástól. Saját eredményeinkhez képest e számolóprogram - mivel klinopiroxén-frakcionáció lehetôségével nem számol — nagymértékben túlbecsülte a primitívmagma MgO-tartalmát két olyan minta esetében (KS, ST), amelyeknél jelentôs klinopiroxén-frakcionációt mutattunk ki.

\section{Kitekintés a modellezés további felhasználási lehetôségére}

A kifejlesztett olivin-frakcionáció modellezés robusztussága következtében használható lehet olyan esetekben is, amikor egy adott kőzetben idegen eredetú magmás olivinkristályok találhatók, amelyek nagy összetételi változékonyságot mutatnak, és ennek eredetét szeretnénk feltárni. Egy ilyen eset bemutatására és a frakcionációs modell tesztelésére a Csomád dácitos lávakôzetében megjelenő, olivin \pm klinopiroxén-tartalmú mafikus kristálycsomók olivinkristályait használtuk fel. Az itt felhasznált olivinösszetételi adatok KIss (2014) PhD disszertációjából származnak.

A Fo-Ni diagramon (6. ábra) az 1. típusú mafikus kristálycsomók (CSOM 1) olivinjei egy Ni-gazdag és egy Niszegény populációt alkotnak, míg a 2. típusú kristálycsomókban (CSOM 2) található olivinek mind Ni-szegények. A legtöbb nikkelt tartalmazó olivin mint kiindulópont és a Persányi-hegység egyik alkáli bazaltos kőzete (BARC) alapján 8-46 között változó $D_{N i}^{o l-o l v}$ érték mellett modelleztük az olivin-frakcionáció okozta Fo-Ni trendeket (6. ábra). E

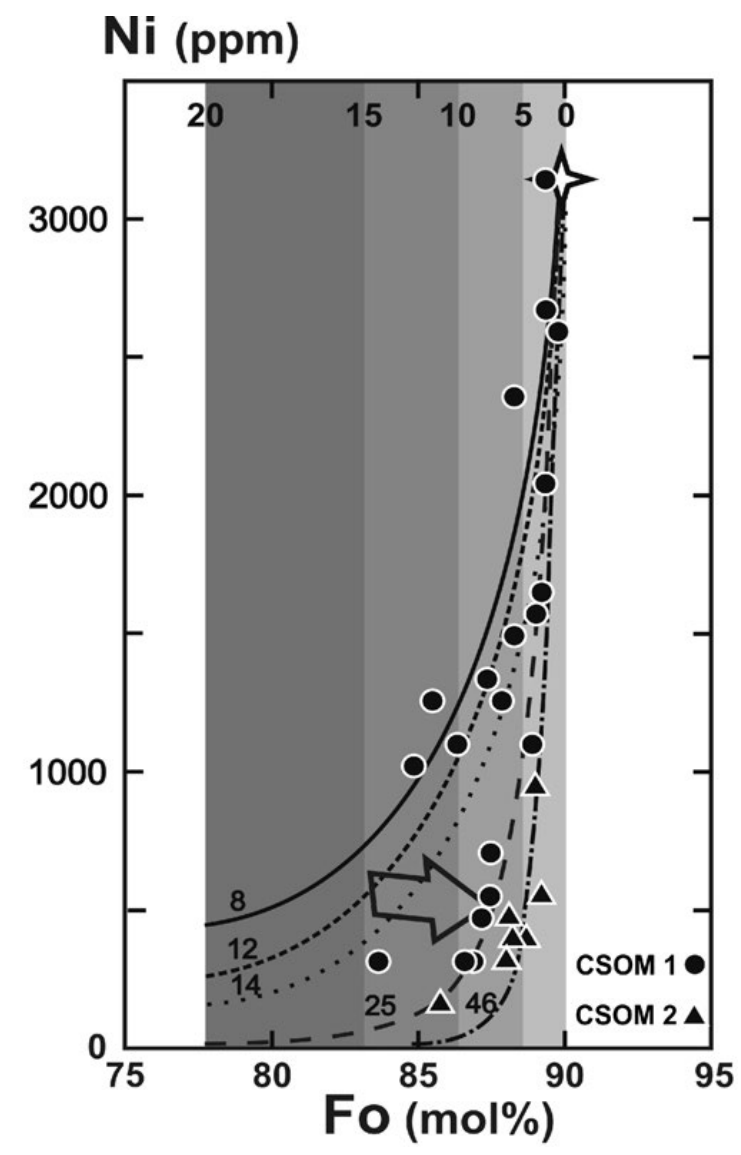

6. ábra. Hipotetikus olivin frakcionáció modellezés a csomádi dácitban megjelenő mafikus kristálycsomók olivin adatai alapján A csillag jelképezi a frakcionáció kiindulópontját. Az egyes görbék a rajtuk jelzett $D_{N i}^{o l-o l v}$ értékkel számolt tisztán olivin-frakcionációt mutatják. A modellezéshez alkáli bazaltként a persányi-hegységi BARC mintát használtuk fel. A különbözó mértékủ $(5,10,15$ és $20 \mathrm{~m} / \mathrm{m} \%)$ olivin frakcionációt szürke sávok jelzik

$\mathrm{Az}$ 1. típusú kristálycsomók (CSOM 1) olivinjei közül a Ni-gazdagok egy 8-14 értékủ alkáli bazaltos olvadékból vezethetők le. Ugyanezen minta Ni-szegény olivinjei javarészt egy sokkal nagyobb Ni olivin-olvadék megoszlási együtthatójú (25) trendre illeszkednek, ugyanakkor túl sok forsteritet tartalmaznak, hogysem a Ni-gazdagabb olivinekkel egyensúlyt tartó magmából frakcionáció útján levezethetők lennének. A Ni-szegény olivinek nagy Fo-tartalma létrejöhetett oxidáció és a vele járó Fe-vesztés révén, erre utalnak a bennük található vas-oxid tủk. Az oxidáció okozta lehetséges Fo-növekedést a fekete nyil mutatja.

A 2. típusú kristálycsomók (CSOM 2) olivinjei Ni-koncentrációjukhoz képest nagyon gazdagok Fo-ben. A persányi-hegységi bazaltminta (BARC) alapján csak irreálisan nagy, 46-os érték mellett vezethetők le alkáli bazalt frakcionációjával. Mivel ezekben az olivinekben vas-oxid tủk nem fordulnak elő és a kristályok gyakorlatilag üdék, a magas Fo-tartalmuk nem magyarázható oxidációval. Annyi bizonyos, hogy a két kristálycsomó típus olivinjei nem származtathatók egyazon bazaltos olvadékból

Figure 6. Hypothetic olivine fractionation modeling based on olivine data from mafic crystal clots of the Csomád dacite

Curves show olivine-only fractionation calculated with the values of $D_{N i}^{o l-l i q}$ that are marked on them. For the modeling composition of an alkaline basalt sample from the Perșani Mt (BARC) was used. Degree of olivine fractionation $(5,10,15$ and $20 \mathrm{wt} . \%)$ is marked by grey shaded bands.

The Ni-rich olivine crystals from the $1^{\text {st }}$ crystal clot type (CSOM 1) could be originate from an alkaline basaltic magma with a $D_{N i}^{o l-l i q}$ value of 8-14. Ni-poor olivines with extremely high Fo-content from the same type fit to an olivine fractionation curve with a much higher value of $D_{N i}^{o l-l i q}(25)$. The submicrometer sized iron oxide needles in them suggest the oxidation of olivine crystals which could led to an anomalously high Fo-content. Possible increase of Fo-content by oxidation are marked with a big black arrow.

Olivines from the $2^{\text {nd }}$ crystal clot type (CSOM 2) have extremely high Fo-content compared to their Ni-concentration. Based on the modeling these high-Fo olvines could precipitate from an alkaline basalt with an unrealistically high value of $D_{N i}^{o l-l i q}(46)$ only. The lack of iron oxide needles in the relatively fresh, unaltered CSOM 2 olivines excludes the possibility of strong oxidation. Therefore it seems clear that the olivine crystals from the two crystal clot types cannot be derived from the same alkaline basaltic melt 
modellezés alapján egyértelmúen kijelenthetô, hogy a két kristálycsomó-típus olivinjei nem származhatnak ugyanabból a szülőmagmából. A modellezéshez ugyanazt a primitív alkáli bazaltos magmaösszetételt felhasználva (BARC) a 2. típus olivinjei frakcionációval csak irreálisan nagy $D_{N i}^{o l-o l v}$ érték (46) mellett vezethető́k le e kiindulási magmaösszetételből, amely messze meghaladja a nikkel elfogadott maximális $D_{N i}^{o l-o l v}$ értékét (VILLEMANT et al. 1981). Erre a jelenségre több lehetséges magyarázat is adható: az olivinek veszíthettek valamelyest az eredeti Ni-tartalmukból, vagy eleve sokkal Niszegényebb magmából származnak, vagy esetleg a $D_{N i}^{o l-o l v}$ felvehet ilyen nagy értéket is (ez a legkevésbé reális lehetőség) — viszont ez utóbbi esetben hiányoznak a Ni-gazdag olivinek a populációból.

Az 1. típusú kristálycsomók olivinjei közül a Ni-ben gazdagabbak reálisan levezethetők egy primitív alkáli bazaltos olvadékból 8-14 közötti $D_{N i}^{o l-o l v}$ értékek mellett. Az 1000 ppm-nél kevesebb nikkelt tartalmazó olivinek viszont sokkal közelebb állnak a 2. típus olivinjeihez, habár azoknál magnéziumban szegényebbek. Amennyiben ezeket a kristályokat önállóan kezeljük, úgy többségük a kiindulási alkáli bazaltból 25-ös $D_{N i}^{o l-o l v}$ érték mellett vezethetô le. Az 1. típusú kristálycsomók olivinjeinek ilyen nagy összetételbeli különbségére a két legvalószínúbb magyarázat: vagy ténylegesen két külön populációt alkotnak, vagy pedig az olivinkristályok egy részének jelentősen megváltozott a Fo- vagy a Ni-tartalma a kristályosodásukat követően. Petrográfiailag semmi nem támasztja alá az elsô lehetôséget, ugyanis az 1. típusú kristálycsomók olivinjei között nem tapasztalható szöveti különbség. Amennyiben egy, azonos populációt feltételezünk, az ilyen kicsi ( $<1000$ ppm) Ni-tartalom mellett túl nagy a Fo mennyisége. Ennek magyarázata lehetne Ni-vesztés vagy Mg-dúsulás is. Az olivin és a szilikátos magmák nikkelre vonatkoztatott megoszlási együtthatója mindig nagyobb, mint 1 (pl. MYSEN 1979, VILLEMANT et al. 1981), azaz Ni-vesztés nem valószínú. Az olivinből oxidáció hatására kiváló vas-oxid túk következtében megnő a Mg aránya, vagyis a Fo-tartalom is (CORTÉs et al. 2006). Mindössze $5 \mathrm{~m} / \mathrm{m} \%$ vas-oxid képződéssel magyarázható lenne a nikkel-szegény olivinek nagy magnéziumtartalma, amely okozhatja a 6 . ábrán látható eltérést a 8-14 $D_{N i}^{o l-o l v}$ értékkel számolt olivin frakcionációs görbéktől. Fontos petrográfiai megfigyelés, hogy az 1. típusú csomókban számos olivinkristály apró vas-oxid túket tartalmaz.

Összességében tehát az olivinek Fo-Ni-tartalma alapján végzett modellezés és a petrográfiai megfigyelések arra utalnak, hogy a két mafikus kristálycsomó típus olivinkristályai nem vezethetốk le egyazon primitív magmából, illetve, hogy egyikük származhat a Persányi-hegységben talál- ható alkáli bazaltok szülőmagmájához hasonlóan primitív olvadékból.

\section{Összegzés}

Modellezésünk lényege és egyben előnye, hogy viszonylag kevés, könnyen mérhetố geokémiai adat alapján, egyszerú lépésekben tudunk becslést adni kontinentális alkáli bazaltok olivin \pm klinopiroxén frakcionációjára, valamint ez alapján a bazaltok szülőmagmájának fóelem-összetételére. További előnye, hogy az ismert és gyakran használt primitívmagmaösszetétel kalkulátorokkal szemben (pl. HERZBERG \& AsIMOw 2008, 2015; LeE et al. 2009) e módszer alkalmas a klinopiroxén-frakcionáció modellezésére és az alkáli bazaltos olvadékok egyedi $D_{N i}^{o l-o l v}$ értékének kiszámítására is.

A modellezéshez szükséges adatok:

1.) a vizsgált kőzet petrográfiai tulajdonságai;

2.) a fenokristályok (mind az olivinek és klinopiroxének) és a kőzet fóelem-összetétele és Ni-koncentrációja.

Modellünk abban az esetben múködik megbízhatóan, ha:

1.) a vizsgált kôzet olivin- vagy olivin- és klinopiroxénfíros, üde alkáli bazalt;

2.) a kôzet — és így a benne található olivinek — nem oxidálódtak;

3.) a kőzetben nincs jelentős mennyiségú Ni-gazdag magnetit vagy földköpeny eredetú olivin xenokristály, és nagyfokú amfibol frakcionáció sem történt.

A modell gyengeségei:

1.) Alacsony maximális Fo- és Ni-koncentrációjú olivinpopuláció esetén a számolást — a kizárólag olivinkristályosodás jellemezte Fo-Ni trend hiányában — nem tudjuk elvégezni.

2) Habár a frakcionáció számolás egyes lépései egyszerúek, a klinopiroxént is tartalmazó kőzetek esetében a számolás igen hosszadalmas és további - fóképp programozási - fejlesztést igényel.

3) Módszerünk nem alkalmas a nagy nyomáson történt, köpenylitoszféra-beli kriptikus klinopiroxén frakcionáció (SMITH et al. 2008) modellezésére/kimutatására.

\section{Köszönetnyilvánítás}

Köszönjük BATKI Anikónak és Kovács Istvánnak a kézirat alapos, részletes és lényegre törő bírálatát. Az elektronmikroszkópos vizsgálatok során nyújtott segítségért BENDŐ Zsoltot illeti köszönet. A tanulmány SÁGI Tamás „ELTE/ 12422/115 (2017)" azonosító számú ÚNKP pályázata révén az Emberi Erőforrások Minisztériuma ÚNKP-17-3 kódszámú Új Nemzeti Kiválóság Programjának támogatásával készült. 


\section{Irodalom — References}

Ali, S. \& NTAFlos, T. 2011: Alkali basalts from Burgenland, Austria: Petrological constraints on the origin of the westernmost magmatism in the Carpathian-Pannonian Region. — Lithos 121, 176-188. https://doi.org/10.1016/j.lithos.2010.11.001

Ali, S., NTAFLos, T. \& UptON, B. G. J. 2013: Petrogenesis and mantle source characteristics of Quaternary alkaline mafic lavas in the western Carpathian-Pannonian Region, Styria, Austria. — Chemical Geology 337-338, 99-113. http://dx.doi.org/10.1016/ j.chemgeo.2012.12.001

BALÁzs E. \& Nusszer A. 1987: Magyarország medenceterületeinek kunsági (pannóniai s. str.) emeletbeli vulkanizmusa. (Unterpannonischer Vulkanismus der Beckengebiete Ungarns). — A Magyar Állami Földtani Intézet Évkönyve 69, 95-113.

Balogh, K., ÁrVA-Sós, E., PÉCSKAY, Z. \& RAVASZ-BARANYAI, L. 1986: K/Ar dating of post-Sarmatian alkali basaltic rocks in Hungary. - Acta Mineralogica Petrographica (Szeged) 28, 75-94.

BALOGH, K., EBNER, F. \& RAVASZ, Cs. 1994: K/Ar-alter Tertiärer Vulkanite der südöstlichen Steiermark und des südlichen Burgenlands. — In: CsÁsZÁR, G. \& DAURER, A. (eds): Jubiläumsschrift 20 Jahre Geologischen Zusammenarbeit Österreich-Ungarn, 55-72.

BAlogh K., Lobitzer, H., PÉcskay Z., RAVASZ C. \& Solti G. 1990: Kelet-Stájerországi és Burgenlandi tercier vulkanitok K/Ar kora. — A Magyar Állami Földtani Intézet Évi Jelentése az 1988. évröl I., 451-468.

CANÓN-TAPIA, E. 2016: Reappraisal of the significance of volcanic fields. - Journal of Volcanology and Geothermal Research 310, 2638. https://doi.org/10.1016/j.jvolgeores.2015.11.010

Cortés, J. A., Wilson, M., Condliffe, E. \& Francalanci, L. 2006: The occurrence of forsterite and highly oxidizing conditions in basaltic lavas from Stromboli volcano, Italy. — Journal of Petrology 47/7, 1345-1373. https://doi.org/10.1093/petrology/eg1012

Demény, A., Vennemann, T. W., Homonnay, Z., Milton, A., Embey-Isztin, A. \& Nagy, G. 2005: Origin of amphibole megacrysts in the Pliocene-Pleistocene basalts of the Carpathian-Pannonian region. - Geologica Carpathica 56/2, 179-189.

Doвosi, G. \& FoDOR, L. 1992: Magma fractionation, replenishment, and mixing as inferred from green-core clinopyroxenes in Pliocene basanite, Southern Slovakia. — Lithos 28, 133-150. https://doi.org/10.1016/0024-4937(92)90028-W

Dobosi, G. \& Jenner, G. A. 1999: Petrologic implications of trace element variation in clinopyroxene megacrysts from the Nograd volcanic province, north Hungary: a study by laser ablation microprobe-inductively coupled plasma-mass spectrometry. — Lithos 46/4, 731-749. https://doi.org/10.1016/S0024-4937(98)00093-0

Dobosi, G., Downes, H., MATTEY, D. \& EMBEY-IszTin, A. 1998. Oxygen isotope ratios of phenocrysts from alkali basalts of the Pannonian basin: evidence for an O-isotopically homogeneous upper mantle beneath a subduction-influenced area. — Lithos 42, 213 -223. https://doi.org/10.1016/S0024-4937(97)00043-1

Dobosi, G., Fodor, R. V. \& GoldberG, S. A. 1995. Late Cenozoic alkali basalt magmatism in Northern Hungary and Slovakia: Petrology, source compositions and relationship to tectonics. - Acta Vulcanologica 7/2, 199-207.

Dobosi, G., Schultz-GütTler, R., Kurat, G. \& Kracher, A. 1991: Pyroxene chemistry and evolution of alkali basaltic rocks from Burgenland and Styria, Austria. — Mineralogy and Petrology 43/4, 275-292. https://doi.org/10.1007/BF01164531

Downes, H., Seghedi, I., Szakacs, A., Dobosi, G., James, D. E., Vaselli, O., Rigby, I. J., Ingram, G.A., ReX, D. \& Pécskay, Z. 1995: Petrology and Geochemistry of Late Tertiary Quaternary Mafic Alkaline Volcanism in Romania. — Lithos 35/1-2, 6581. https://doi.org/10.1016/0024-4937(95)91152-Y

Embey-Isztin, A. \& Dobosi, G. 1995. Mantle source characteristics for Miocene-Pleistocene alkali basalts, Carpathian-Pannonian Region: a review of trace elements and isotopic composition. - Acta Vulcanologica 7/2, 155-166.

Embey-Isztin, A. \& Dobosi, G. 2007: Composition of olivines in the young alkali basalts and their peridotite xenoliths from the Pannonian Basin. - Annales Musei Historico-naturalis Hungarici 99, 5-22.

Embey-Isztin, A., Downes, H. \& Dobosi, G. 2001. Geochemical characterization of the Pannonian Basin mantle lithosphere and asthenosphere: an overview. - Acta Geologica Hungarica 44, 259-280.

Embey-Isztin, A., Downes, H., James, D. E., Upton, B. G. J., Dobosi, G., Ingram, G. A., Harmon, R. S. \& Scharbert, H. G. 1993a: The Petrogenesis of Pliocene Alkaline Volcanic-Rocks from the Pannonian Basin, Eastern Central-Europe. _ Journal of Petrology 34/2, 317-343. https://doi.org/10.1093/petrology/34.2.317

Embey-Isztin, A., Dobosi, G., James, D., Downes, H., Poultidis Ch. \& Scharbert H. G. 1993b: A compilation of new major, trace element and isotope geochemical analyses of the young alkali basalts from the Pannonian Basin. — Fragmenta Mineralogica et Palaeontologica 16, 5-26.

Fillerup, M. A., Knapp, J. H., Knapp, C. C. \& Railanu, V. 2010: Mantle earthquakes in the absence of subduction? Continental delamination in the Romanian Carpathians. — Lithosphere 2/5, 333-340. https://doi.org/10.1130/L102.1

GîRBACEA, R. \& FRISCH, W. 1998: Slab in the wrong place: lower lithospheric mantle delamination in the last stage of the Eastern Carpathian subduction retreat. — Geology 26/7, 611-614. https://doi.org/10.1130/0091-7613(1998)026<0611:SITWPL >2.3.CO;2

HARANGi, R. \& HARANGI, Sz. 1995: Volcanological study of the Neogene basaltic volcano of Ság-hegy (Little Hungarian Plain volcanic field, Western Hungary). - Acta Vulcanologica 7/2, 189-197.

HARANGI, Sz. 2001: Neogene to Quaternary volcanism of the Carpathian-Pannonian Region — a review. — Acta Geologica Hungarica 44 2-3, 223-258.

HARANGi Sz. 2007: A Kárpát-Pannon térség legutolsó vulkáni kitörései — lesz-e még folytatás? (The last volcanic eruptions in the Carpathian-Pannonian Region — to be continued?). — Földrajzi Közlemények 131/4, 271-288.

Harangi, Sz. \& LenKey, L. 2007: Genesis of the Neogene to Quaternary volcanism in the Carpathian-Pannonian region: Role of subduction, extension, and mantle plume. - In: BecCAluva, L., BiAnChInI, G. \& Wilson, M. (eds): Cenozoic Volcanism in the Mediterranean Area Geological Society of America, Boulder, Colorado (USA), 67-92.

Harangi, Sz., Vaselli, O., Tonariniz C., Szabó Cs., Harangi, R. \& Coradossi, R. 1995: Petrogenesis of Neogene extension-related alkaline volcanic rocks of the Little Hungarian Plain Volcanic Field (western Hungary). — Acta Vulcanologica 7/2, 173-188. 
Harangi, Sz., Molnár, M., Vinkler, A.P., Kiss, B., Jull, A. T. J. \& LeOnard, A. G. 2010: Radiocarbon dating of the last volcanic eruptions of Ciomadul Volcano, Southeast Carpathians, Eastern-Central Europe. — Radiocarbon 52/3, 1498-1507. https://doi.org/10.1017/S0033822200046580

Harangi, Sz., SÁgi, T., Seghedi, I. \& Ntaflos, T. 2013: A combined whole-rock and mineral-scale investigation to reveal the origin of the basaltic magmas of the Perşani monogenetic volcanic field, Romania, eastern-central Europe. — Lithos 180-181, $43-57$. https://doi.org/10.1016/j.lithos.2013.08.025

Harangi, Sz., Jankovics, M.É., SÁGi, T., Kiss, B., LuKÁcs, R. \& Soós, I. 2015: Origin and geodynamic relationships of the late Miocene to quaternary alkaline basalt volcanism in the Pannonian basin, eastern-central Europe. - International Journal of Earth Sciences 104, 2007-2032. https://doi.org/10.1007/s00531-014-105-7

HART, S. R. \& DAVIS, K. E. 1978: Nickel Partitioning between Olivine and Silicate Melt. — Earth and Planetary Science Letters 40/2, 203-219. https://doi.org/10.1016/0012-821X(78)90091-2

HerzBERG, C. 2011: Identification of source lithology in the Hawaiian and Canary Islands: implications for origins. — Journal of Petrology 52, 113-146. https://doi.org/10.1093/petrology/egq075

HerzberG, C. \& Asimow, P. D. 2008: Petrology of some oceanic island basalts: PRIMELT2.XLS software for primary magma calculation. — Geochemistry, Geophysics, Geosystems 9, Q09001. http://dx.doi.org/10.1029/2008GC002057

HERZBERG, C. \& AsIMOw, P. D. 2015: PRIMELT3 MEGA.XLSM software for primary magma calculation: peridotite primary magma MgO contents from the liquidus to the solidus. — Geochemistry, Geophysics, Geosystems 16, 563-578. http://dx.doi.org/ 10.1002/2014GC005631

HerzBerg, C. \& O'HARA, M. J. 2002: Plume-associated ultramafic magmas of phanerozoic age. — Journal of Petrology 43/10, 18571883. https://doi.org/10.1093/petrology/43.10.1857

Herzberg, C., Asimow, P. D., Arndt, N. T., Niu, Y., Lesher, C. M., Fitton, J. G., Cheadle, M. J. \& Saunders, A. D. 2007: Temperatures in ambient mantle and plumes: constraints from basalts, picrites and komatiites. - Geochemistry, Geophysics, Geosystems 8, Q02006. http://dx.doi.org/10.1029/2006GC001390

INKEY B. 1878: Két magyarhoni doleritről. — Földtani Közlöny 8, 223-231.

JANKovics, M. É., HARANGi, Sz. \& NTAFlos, T. 2009. A mineral-scale investigation of the origin of the 2.6 Ma Füzes-tó basalt, BakonyBalaton Highland Volcanic Field (Pannonian Basin, Hungary). — Central European Geology 52/2, 97-124. https://doi.org/10.1556/ CEuGeol.52.2009.2.1

JANKovics, M. É., HARAngi, Sz., Kiss, B. \&, NTAFlos, T. 2012: Open-system evolution of the Fuzes-to alkaline basaltic magma, western Pannonian Basin: Constraints from mineral textures and compositions. — Lithos 140, 25-37. https://doi.org/10.1016/ j.lithos.2012.01.020

Jankovics, M. É., Dobosi, G., Embey-Isztin, A., Kiss, B., SÁgi, T., Harangi, S. \& NTaflos, T. 2013: Origin and ascent history of unusually crystal-rich alkaline basaltic magmas from the western Pannonian Basin. — Bulletin of Volcanology 75, 749. https://doi.org/10.1007/s00445-013-0749-7

Jankovics, M. É., Harangi, Sz., Németh, K., Kiss, B. \& Ntaflos, T. 2015: A complex magmatic system beneath the Kissomlyó monogenetic volcano (western Pannonian Basin): evidence from mineral textures, zoning and chemistry. — Journal of Volcanology and Geothermal Research 301, 38-55.

Jankovics, M. É., Taracsák, Z., Dobosi, G., Embey-Isztin, A., Batki, A., Harangi, Sz. \& Hauzenberger, Ch. A. 2016: Clinopyroxene with diverse origins in alkaline basalts from the western Pannonian Basin: Implications from trace element characteristics. — Lithos 262, 120-134. https://doi.org/10.1016/j.lithos.2016.06.030

Jugovics L. 1937: A Sághegy felépítése és vulkánologiai viszonyai. — Magyar Tudományos Akadémia Mathematikai és Természettudományi Értesító 56, 1214-1235.

JuGOVICs L. 1948: Adatok Tátika-Prága-Sarvaly-hegyek vulkánológiai felépítéséhez. — Földtani Közlöny 78, 196 -205.

Jugovics L. 1972: A Kisalföld bazalt és bazalttufa előfordulásai. — Magyar Állami Földtani intézet évi jelentése az 1970. évról, 79-101.

Kawabata, H., Hanyu, T., Chang, Q., Kimura, J. I., Nichols, A. R. L. \& Tatsumi, Y. 2011: The Petrology and Geochemistry of St. Helena Alkali Basalts: Evaluation of the Oceanic Crust-recycling Model for HIMU OIB. - Journal of Petrology 52/4, 791-838. https://doi.org/10.1093/petrology/egr003

Karátson, D., Telbisz, T., Harangi, Sz., Magyari, E., Dunkl, I., Kiss, B., Jánosi, C., Veres, D., Braun, M., Fodor, E., Biró, T., Kósik, S., von EynATTEN, H. \& Lin, D. 2013: Morphometrical and geochronological constraints on the youngest eruptive activity in East-Central Europe at the Ciomadul (Csomád) lava dome complex, East Carpathians. - Journal of Volcanology and Geothermal Research 255, 43-56. https://doi.org/10.1016/j.jvolgeores.2013.01.013

Karátson, D., Wulf, S., Veres, D., Magyari, E. K., Gertisser, R., Timar-Gabor, A., Novothny, Á., Telbisz, T., Szalai, Z., Anechitei-Dacu, V., Appelt, O., Bormann, M., Jánosi, Cs., Hubay, K. \& SchäBItz, F. 2016: The latest explosive eruptions of Ciomadul (Csomad) volcano, East Carpathians — A tephrostratigraphic approach for the 51-29ka BP time interval. — Journal of Volcanology and Geothermal Research 319, 29-51. https://doi.org/10.1016/j.jvolgeores.2016.03.005

KimURA, J.-I., \& KaWABATA, H. 2015: Ocean Basalt Simulator version 1 (OBS1): Trace element mass balance in adiabatic melting of a pyroxenite-bearing peridotite. - Geochemistry, Geophysics, Geosystems 16, 267-300. http://dx.doi.org/10.1002/2014GC005606

KIss B. 2014: A csomádi dácit petrogenezise: következtetések a magmatározó-rendszer felépítésére és folyamataira. — PhD értekezés, ELTE Kőzettan-Geokémiai Tanszék, Budapest 140 p.

Kiss, B., Harangi, Sz., Ntaflos, T., Mason, P. R. D. \& Pál-Molnár, E. 2014: Amphibole perspective to unravel pre-eruptive processes and conditions in volcanic plumbing systems beneath intermediate arc volcanoes: a case study from Ciomadul volcano (SE Carpathians). — Contributions to Mineralogy and Petrology 167, 986. https://doi.org/10.1007/s00410-014-0986-6

KoneČNÝ, V., LEXA, J. \& BALOGH, K. 1999: Neogene-Quaternary alkali basalt volcanism of Slovakia: Review of volcanic forms and evolution. - Geologica Carpathica 50, 112-115. 
Kovács, I., Falus Gy., Stuart, G., Hidas, K., Szabó, Cs., Flower, M. F. J., Hegedús, E., Posgay, K. \& Zilahi-Sebess, L. 2012: Seismic anisotropy and deformation patterns in upper mantle xenoliths from the central Carpathian-Pannonian region: Asthenospheric flow as a driving force for Cenozoic extension and extrusion? - Tectonophysics 514, 168-179. https://doi.org/ 10.1016/j.tecto.2011.10.022

Kováč, M., Márton, E., Oszczypko, N., Vojtko, R., Hók, J., Králikpvá, S., Plašienka, D., Klučiar, T., HudáčKová, N. \& OSZCZYPKO-ClowES, M. 2017: Neogene palaeogeography and basin evolution of the Western Carpathians, Northern Pannonian domain and adjoining areas. — Global and Planetary Change 155, 133-154. https://doi.org/10.1016/j.gloplacha.2017.07.004

Laubier, M., Grove, T. L. \& LANGMuir, C. H. 2014: Trace element mineral/melt partitioning for basaltic and basaltic andesitic melts: An experimental and laser ICP-MS study with application to the oxidation state of mantle source regions. — Earth and Planetary Science Letters 392, 265-278. https://doi.org/10.1016/j.eps1.2014.01.053

Le Bas, M. J., Lemaitre, R. W. \& Woolley, A. R. 1992: The Construction of the Total Alkali-Silica Chemical Classification of Volcanic-Rocks. — Mineralogy and Petrology 46/1, 1-22. https://doi.org/10.1007/BF01160698

LeE, C.-T. A., LufF, P., Plank, T., Dalton, H. \& LeEman, W. P. 2009: Constraints on the depths and temperatures of basaltic magma generation on Earth and other terrestrial planets. — Earth and Planetary Science Letters 279, 20-33. https://doi.org/10.1016/ j.epsl.2008.12.020

Lemarchand, F., Villemant, B. \& Calas, G. 1987: Trace-Element Distribution Coefficients in Alkaline Series. - Geochimica et Cosmochimica Acta 51/5, 1071-1081. https://doi.org/10.1016/0016-7037(87)90201-8

Martin, U. \& NÉMETH, K. 2004: Mio/Pliocene Phreatomagmatic Volcanism in the Western pannonian Basin. _ Geologica Hungarica, series Geologica 26, 192 p.

MARTIN, U. \& NÉMETH, K. 2005: Eruptive and depositional history of a Pliocene tuff ring that developed in a fluvio-lacustrine basin: Kissomlyó volcano (western Hungary). — Journal of Volcanology and Geothermal Research 147/3-4, 342-356. https://doi.org/ 10.1016/j.jvolgeores.2005.04.019

Mason, P. R. D., SEghedi, I., SzaKÁcs, A. \& Downes, H. 1998: Magmatic constraints on geodynamic models of subduction in the East Carpathians, Romania. — Tectonophysics 297, 157-176. https://doi.org/10.1016/S0040-1951(98)00167-X

Mattsson, H. B. 2012: Rapid magma ascent and short eruption durations in the Lake Natron-Engaruka monogenetic volcanic field (Tanzania): A case study of the olivine melilititic Pello Hill scoria cone. - Journal of Volcanology and Geothermal Research 247, 16-25. https://doi.org/10.1016/j.jvolgeores.2012.07.009

Mauritz B. \& Harwood, H. F. 1937a: A celldömölki Sághegy bazaltos kőzete. — Magyar Tudományos Akadémia Mathematikai és Természettudományi Értesítô 55, 938-958.

Mauritz B. \& Harwood, H. F. 1937b: A Tátika-csoport bazaltos kőzetei. - Magyar Tudományos Akadémia Mathematikai és Természettudományi Értesító 55, 75-103.

Mauritz B., Harwood, H. F., THeobald, L. S. \& EndrÉdy, E. 1948: A Dunántúli bazaltok kőzetkémiai viszonyai. — Földtani Közlöny 78, 134-169.

McGee, L. E., Beier, C., Smith, I. E. M. \& Turner, S. P. 2011: Dynamics of melting beneath a small-scale basaltic system: a U-Th-Ra study from Rangitoto volcano, Auckland volcanic field, New Zealand. — Contributions to Mineralogy and Petrology 162/3, 547563. https://doi.org/10.1007/s00410-011-0611-x

McGee, L. E., Smith, I. E. M., Millet, M. A., Handley, H. K. \& Lindsay, A. M. 2013: Asthenospheric Control of Melting Processes in a Monogenetic Basaltic System: a Case Study of the Auckland Volcanic Field, New Zealand. — Journal of Petrology 54/10, 21252153. https://doi.org/10.1093/petrology/egt043

MYsEn, B. O. 1979: Nickel partitioning between olivine and silicate melt: Henry's law revisited. — American Mineralogist 64, 11071114.

NÉMETH, K. 2010: Volcanic glass textures, shape characteristics and compositions of phreatomagmatic rock units from the Western Hungarian monogenetic volcanic fields and their implications for magma fragmentation. - Central European Journal of Geosciences 2/3, 399-419. https://doi.org/10.2478/v10085-010-0015-6

NÉMETH, K. \& KERESZTURI, G. 2015: Monogenetic volcanism: personal views and discussion. — International Journal of Earth Sciences 104/8, 2131-2146. https://doi.org/10.1007/s00531-015-1243-6

NiU, Y. \& O'HARA, M. 2003: Origin of ocean island basalts: a new perspective from petrology, geochemistry, and mineral physics considerations. - Journal of Geophysical Research 108, 2209-2228. http://dx.doi.org/10.1029/2002JB002048

Pécskay, Z., Lexa, J., Szakács, A., Balogh, K., Seghedi, I., Konecny, V., Kovács, M., Márton, E., Kaliciak, M., Széky-Fux, V., Póka, T., Gyarmati, P., Edelstein, O., Rosu, E. \& Zec, B. 1995: Space and time distribution of Neogene-Quaternary volcanism in the Carpatho-Pannonian Region. - Acta Vulcanologica 7/2, 15-28.

Peltz, S., VAjdeA, E., Balogh, K. \& PÉCSKAY, Z. 1987: Contributions to the geochronological study of the volcanic processes int he Calimani and Hargitha Mountains (East Carpathians, Romania). — D. S. Institutul de Geologie şi Geofizică 72, 323 p.

Pilet, S., BAKER, M. B. \& STOLPER E.M. 2008: Metasomatized Lithosphere and the Origin of Alkaline Lavas. — Science 320 (5878), 916-919. https://doi.org/10.1126/science.1156563

Pouchou, J. L. \& PICHOIR, F. 1991: Quantitative Analysis of Homogeneous or Stratified Microvolumes Applying the Model "PAP”. In: HeINRICH, K. F. J. \& Newbury D. E. (eds): Electron Probe Quantitation. Springer, Boston, 31-75. https://doi.org/10.1007/978-14899-2617-3_4

PUTIRKA, K. D. 2005: Mantle potential temperatures at Hawaii, Iceland, and the mid-ocean ridge system, as inferred from olivine phenocrysts: Evidence for thermally driven mantle plumes. - Geochemistry, Geophysics, Geosystems 6, Q05L08. http://dx.doi.org/10.1029/2005GC000915

Putirka, K. D., Perfit, M., Ryerson, F. J. \& JaCKson, M.G. 2007: Ambient and excess mantle temperatures, olivine thermometry, and active vs. passive upwelling. — Chemical Geology 241/3-4, 177-206. https://doi.org/10.1016/j.chemgeo.2007.01.014 
SÁGI T. 2008: Petrogenetikai következtetések a Pannon-medence nyugati részén előforduló alkáli bazaltok képződésére olivin és spinell összetétel adatok alapján. — Diplomamunka, ELTE Kőzettan-Geokémiai Tanszék, 93 p.

SAto, H. 1977: Nickel Content of Basaltic Magmas - Identification of Primary Magmas and a Measure of Degree of Olivine Fractionation. — Lithos 10/2, 113-120. https://doi.org/10.1016/0024-4937(77)90037-8

Seghedi, I., Downes, H., Vaselli, O., Szakács, A., Balogh, K., \& PÉcskay, Z. 2004: Post-collisional Tertiary-Quaternary mafic alkalic magmatism in the Carpathian-Pannonian region: A review. — Tectonophysics 393, 43-62. https://doi.org/10.1016/j.tecto.2004.07.051

Seghedi, I., Mațenco, L., Downes, H., Mason, P. R. D., Szakács, A. \& PécsKay, Z. 2011: Tectonic significance of changes in postsubduction Pliocene-Quaternary magmatism in the south east part of the Carpathian-Pannonian Region. - Tectonophysics 502/1-2, 146-157. https://doi.org/10.1016/j.tecto.2009.12.003

Seghedi, I., Popa, R. G., PANAiotu, C. G., SZAKÁCS, A. \& PÉCSKAy, Z. 2016: Short-lived eruptive episodes during the construction of a Na-alkalic basaltic field (Perşani Mountains, SE Transylvania, Romania). — Bulletin of Volcanology 78: 69. https://doi.org/10.1007/ s00445-016-1063-y

ŠImon. \& Maglay, J. 2005: Dating of sediments underlying the Putikov vrsok volcano lava flow by the OSL method. — Mineralia Slovaca 37, 7-40.

Smith, I. E. M., Blake, S., Wilson, C. J. N. \& Houghton, B. F. 2008: Deep-seated fractionation during the rise of a small-volume basalt magma batch: Crater Hill, Auckland, New Zealand. — Contributions to Mineralogy and Petrology 155/4, 511-527. https://doi.org/ 10.1007/s00410-007-0255-z

SzaKÁCS, A. \& SEghedi, I. 1995: The Călimani-Gurghiu-Harghita volcanic chain, East Carpathians, Romania: volcanological features. - Acta Vulcanologica 7/2, 145-153.

SZAKÁCS, A. \& SEGHEDI, I. 2013: The relevance of volcanic hazard in Romania: is there any? - Environmental Engineering and Management Journal 12, 125-135.

SZAKÁCs, A., SEghedi, I. \& PÉCSKAY, Z. 1993: Peculiarities of South Harghita Mts. as the terminal segment of the Carpathian Neogene to Quaternary volcanic chain. - Revue Roumaine de Géologie Géophysique et Géographie, Géologie 37, 21-37.

SZAKÁCS, A., SEGHEdI, I. \& PÉCSKAY, Z. 2002: The most recent volcanism in the Carpathian-Pannonian Region. Is there any volcanic hazard? - Geologica Carpathica 53, 193-194.

TschegG, C., NTAFlos, T., Kiraly, F. \& Harangi, Sz. 2010: High temperature corrosion of olivine phenocrysts in Pliocene basalts from Banat, Romania. - Austrian Journal of Earth Sciences 103, 101-110.

Valentine, G. A. \& Connor, B. C. 2015: Basaltic Volcanic Fields. — In: Sigurdsson, H. (ed.): The Encyclopedia of Volcanoes (Second Edition). Academic Press, London, 423-439. https://doi.org/10.1016/B978-0-12-385938-9.00023-7

Villemant, B., JafFrezic, H., Joron, J. L. \& Treuil, M. 1981: Distribution Coefficients of Major and Trace-Elements - Fractional Crystallization in the Alkali Basalt Series of Chaine-Des-Puys (Massif Central, France). — Geochimica et Cosmochimica Acta 45/11, 1997-2016. https://doi.org/10.1016/0016-7037(81)90055-7

Vinkler A. P., Harangi Sz., NTAFlos, T. \& SzaKÁCS, A. 2007: A Csomád vulkán (Keleti-Kárpátok) horzsaköveinek kőzettani és geokémiai vizsgálata — petrogenetikai következtetések. — Földtani Közlöny 137/1, 103-128.

Wijbrans, J., NÉmeth, K., MARTin, U. \& BALOGH, K. 2007: ${ }^{40} \mathrm{Ar} /{ }^{39} \mathrm{Ar}$ geochronology of Neogene phreatomagmatic volcanism in the western Pannonian Basin, Hungary. — Journal of Volcanology and Geothermal Research 164/4, 193-204. https://doi.org/10.1016/ j.jvolgeores.2007.05.009

Zajacz, Z., Kovács, I., Szabó, Cs., Halter, W. \& PettKe, T. 2007: Evolution of mafic alkaline melts crystallized in the uppermost lithospheric mantle: a melt inclusion study of olivine-clinopyroxenite xenoliths, northern Hungary. — Journal of Petrology 48/5, 853-883. https://doi.org/10.1093/petrology/egm004

Kézirat beérkezett: 2018. 02. 16. 